\title{
Recent Developments in Low iLUC Policies and Certification in the EU Biobased Economy
}

\author{
Beike Sumfleth $^{1, * \mathbb{C}}$, Stefan Majer ${ }^{1}\left(\mathbb{D}\right.$ and Daniela Thrän ${ }^{1,2}$ \\ 1 German Biomass Research Centre (DBFZ), 04347 Leipzig, Germany; \\ stefan.majer@dbfz.de (S.M.); daniela.thraen@ufz.de (D.T.) \\ 2 Helmholtz Centre for Environmental Research (UFZ), 04318 Leipzig, Germany \\ * Correspondence: beike.sumfleth@dbfz.de; Tel.: +49-341-2434-575
}

Received: 31 August 2020; Accepted: 29 September 2020; Published: 2 October 2020 updates

\begin{abstract}
The development of a sustainable biobased economy (BBE) in Europe is associated with several challenges. Amongst others, lessons learned from the development of the biofuel sector and the complex debate around land use change associated with a growing demand for biomass have to be considered when developing BBE policies. In that regard, strategies to identify and verify feedstocks with low potential risks for direct and indirect land use change (iLUC) impacts are of specific importance. Complementing existing efforts to assess iLUC with modelling activities, the European Commission (EC) has proposed a risk-based approach, aiming to differentiate high and low iLUC risk biomass. Amongst others, different additionality measures can be used to produce certified biomass with low iLUC risk. However, a comprehensive overview and analysis of these additionality measures and the challenges related to their integration in an integer verification approach is still missing. Therefore, we analyse European Union (EU) policies dealing with iLUC, iLUC risk assessment studies, certification approaches, and iLUC modelling studies to identify and develop additionality practices potentially applicable in certification and to show how the potential application of the proposed measures could be realised and verified in practice. We identified five potential practices for low iLUC risk biomass production, which are likely to be used by market actors. For each practice, we identified methods for the determination of low iLUC risk feedstock and products. Finally, our review includes recommendations for follow-up activities towards the actual implementation of additionality measures in biomass certification schemes.
\end{abstract}

Keywords: iLUC; risk; additionality; certification; sustainability; biobased economy; EU policy

\section{Introduction}

Future projections expect a growing biobased economy (BBE) in the next decades [1]. This is characterised by an increasing use of biomass for energy purposes, like biofuels and a growing demand for biobased materials [2]. The latter comprise i.e., bioplastics, biochemicals, biolubricants, biosolvents, and biosurfactants [3]. For the manufacturing of these products, feedstocks obtained from the use of agricultural land are of essential importance [4]. This might increase the demand for land to cultivate those feedstocks $[5,6]$. To meet that growing demand, the cultivated area, on the one hand, might expand to currently uncultivated land and on the other hand might occupy cultivated area, worldwide [7]. That could result in higher pressure on land, which was not cultivated before, with increasing impacts on biodiversity and carbon stock [8,9]. Land use change (LUC) could be one of the consequences. Land use change can be categorised into direct land use change (dLUC) and indirect land use change (iLUC). According to the Intergovernmental Panel on Climate Change (IPCC), dLUC is defined as a change in the use or management of land by humans, which may lead to a change in land cover. Whereas iLUC refers to shifts in land use induced by a change in the 
production level of an agricultural product somewhere else in the world. This change can be the consequence of market mechanisms or political measures inducing additional demand for biomass or land [10]. Therefore, the decision to change agricultural land use activities of a particular location could also change land use activities globally or locally. The particular characteristic of iLUC is that the displacement of other land use activities, which could for example be caused by an increase in biomass production for the manufacture of biobased products, is decoupled from the production of the biobased product itself. For example, if soybeans from existing soybean farmland originally used for food and feed production are used to produce soybean-based biodiesel, the cultivation of soybeans for food and feed purposes could be shifted to previously unused land somewhere in the world. This displacement could take place across national borders, which in turn could make it more difficult to trace LUC, and thus increase the decoupling of feedstock production of biobased products from its impact [11]. While dLUC is easy to monitor and quantify, iLUC effects are more complex, because it is influenced by many different factors, such as (i) an increasing demand for biomass, worldwide, (ii) an increase in the price of food crops, (iii) environmental policies lead to leakage effects like unintended land use displacements, (iv) spatially varying crop yields, (v) and the globalised trade of biobased products [12-15]. Therefore, iLUC could occur worldwide, with significant time lags and might be strongly influenced by global trade [16]. The dilemma with iLUC was recognised under the EU Renewable Energy Directive (RED) [17], when sustainability criteria for biofuels guaranteed the origin from established cultivation areas, but came along with the expansion of cultivation areas for food, feed, and material purposes [18]. Figure 1 shows the interconnection between EU policies dealing with iLUC and relevant iLUC modelling studies. The results of the modelling had a significant impact on the development of the respective EU policies. The results of the MIRAGE (Modelling International Relationship in Applied General Equilibrium) study [19] and the GLOBIOM (Global Biosphere Management) study [20] played an important role in the further development of the RED. As already mentioned, the RED introduced the certification of biofuels that are produced in compliance with sustainability criteria. Nevertheless, with the RED 2 there was a change in focus towards an approach whose goal is to reduce the iLUC risk [21]. For this purpose, the RED 2 is supplemented by a delegated regulation, which names so-called additionality measures. According to this, low iLUC risk biomass must be produced in compliance with these additionality measures in order to be certified [22].

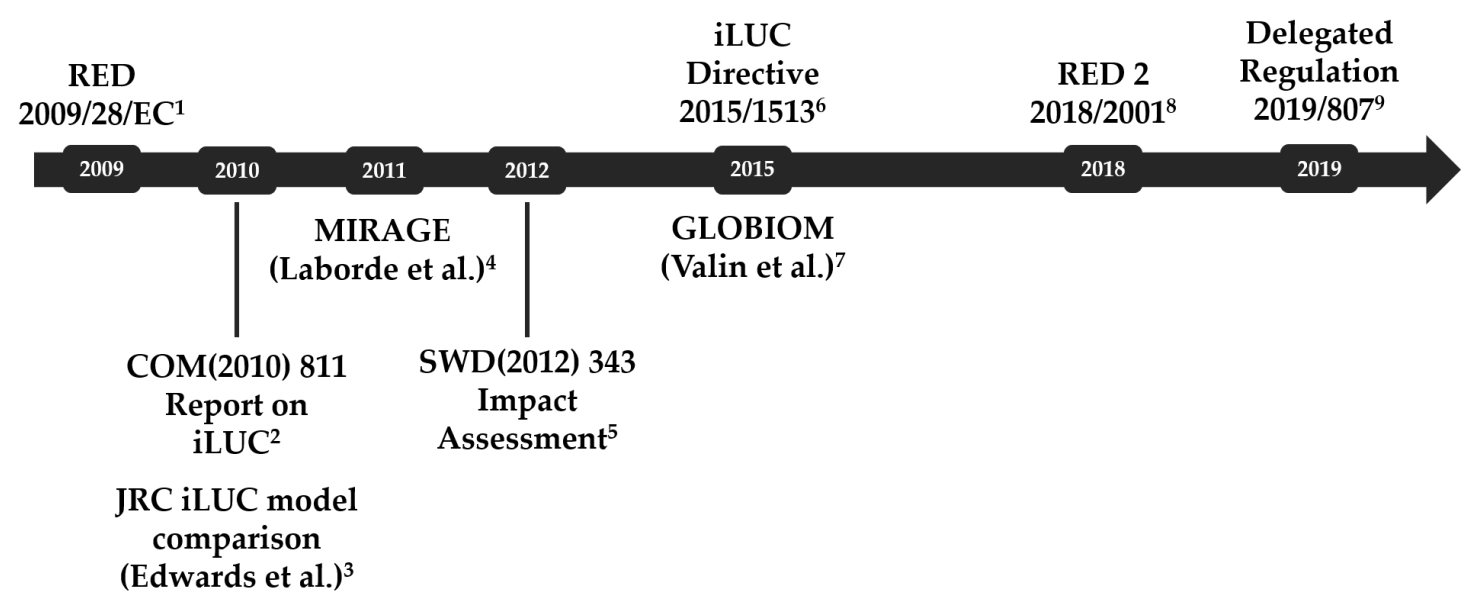

Figure 1. Timeline of EU policies dealing with indirect land use change (iLUC) and relevant iLUC modelling approaches $\left({ }^{1}\right.$ Renewable Energy Directive [17], ${ }^{2}$ Report from the Commission on indirect land-use change related to biofuels and bioliquids [18], ${ }^{3}$ [23], ${ }^{4}$ [19], ${ }^{5}$ Commission Staff Working Document Impact Assessment [24], ${ }^{6}[25],{ }^{7}[20],{ }^{8}$ Renewable Energy Directive 2 [21], ${ }^{9}$ [22]). 


\subsection{Approaches to Quantify the iLUC Effects of Biofuel Policies}

An assessment of indirect impacts caused by the production of biofuels from US corn conducted by Searchinger et al. [26] in the year 2008 is one of the first attempts to quantify the effects of iLUC. This analysis was complemented by other iLUC quantification approaches, mostly related to policy targets (e.g., the target for the share of renewables in the EU transport sector as defined by the RED) $[27,28]$. Most of these quantification approaches use models to estimate the contribution of iLUC to the overall Green House Gas (GHG) emissions balance of biofuels [29]. In this sense, the respective iLUC modelling approaches take into account emissions caused by the conversion of land to cropland due to the loss of existing above and below ground biomass [23].

According to De Rosa et al. [30], the models can be grouped into Economic Equilibrium Models (EEM), Causal-Descriptive Models (CDM), and Normative Models (NM). Whereas, the EEM base on economic equilibrium theory and include Computable General Equilibrium (CGE) models and Partial Equilibrium (PE) models [30]. A recently conducted review of iLUC assessment and quantification approaches distinguish between four modelling types, as Figure 2 illustrates [31]. Panichelli and Gnansounou [32] identify several other LUC modelling approaches, e.g., optimisation models, biophysical models, and system dynamics models for the estimation of LUC GHG emissions from biofuels production. Henders and Ostwald [33] highlight strengths and weaknesses of several EEM and CDM approaches. A comprehensive overview of different iLUC modelling activities can be found in $[34,35]$.
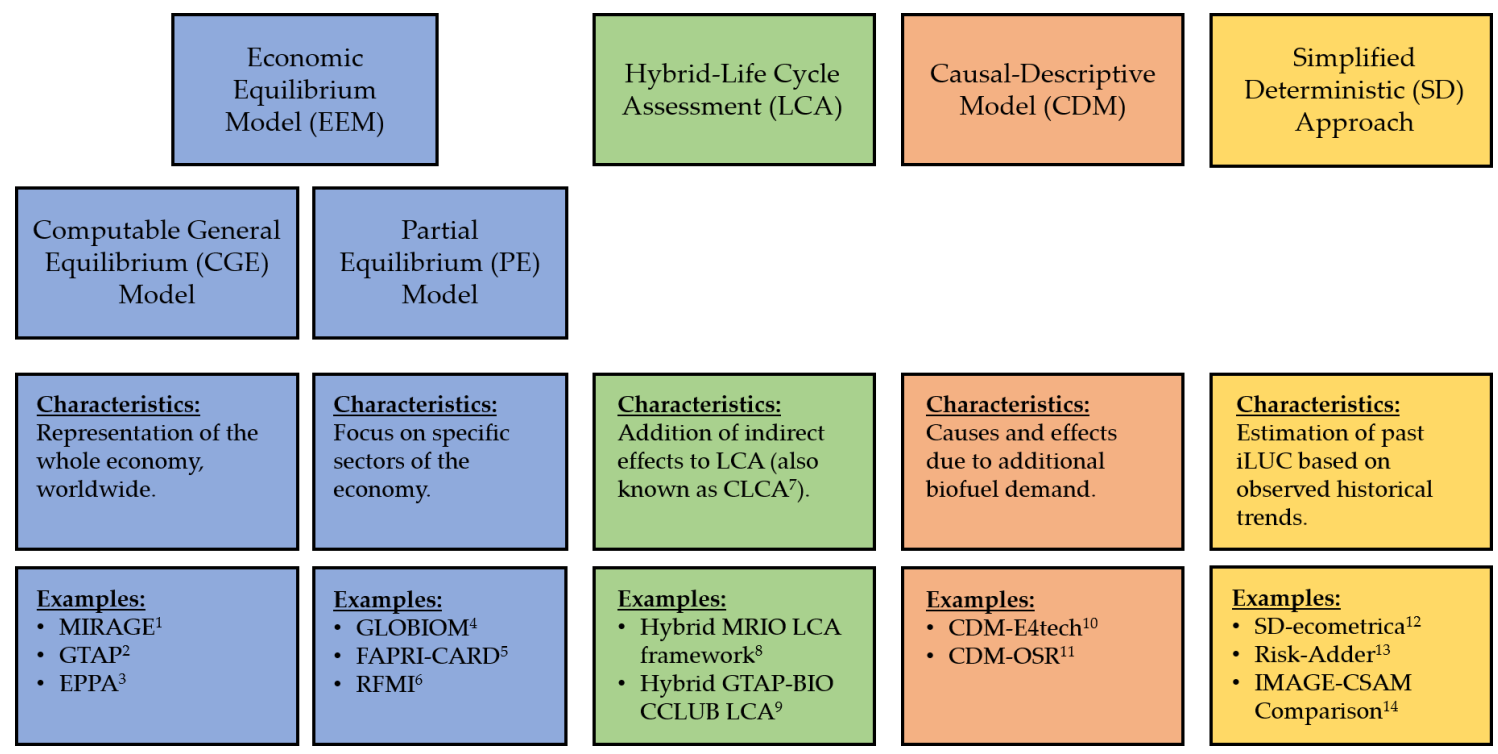

Figure 2. Land use change (LUC) modelling approaches with main characteristics based on results of Daioglou et al. [31] and examples. ${ }^{1}[19,36,37] ;{ }^{2}[38,39] ;{ }^{3}[40] ;{ }^{4}[20] ;{ }^{5}[26] ;{ }^{6}[41] ;{ }^{7}$ Consequential Life Cycle Assessment; ${ }^{8}[42] ;{ }^{9}[43] ;{ }^{10}[44] ;{ }^{11}[45] ;{ }^{12}[46] ;{ }^{13}[16] ;{ }^{14}[47]$.

The models estimate the annualised iLUC GHG emissions intensity, expressed in $\mathrm{g} \mathrm{CO}_{2} \mathrm{e} \mathrm{MJ}{ }^{-1}$ biofuel, also known as iLUC emission factor [48]. Figure 3 shows exemplarily the iLUC emission factors of several biofuels made from different feedstock. For each biofuel path, the results of different modelling approaches are shown. The results underline that iLUC is a key issue for the implementation of policies aimed at increasing the use of biofuels as a tool to mitigate climate change. However, due to the different modelling results, it is not possible to provide clear information on the exact level of GHG emissions caused by iLUC for each biofuel. The results of the modelling approaches (e.g., CGE, PE, or CDM) differ considerably due to several factors as follows (taken from [15,49-51]): 
(i) Structural components of the models: CGE models are developed for the whole economy, whereas PE models are developed only for specific sectors. There are differences in the geographical and commodity-level resolution. Furthermore, additional reasons for uncertainties could be to model trade of biofuels and the expansion of cultivated land into different land use types. The focus of many studies is on first-generation biofuels. Furthermore, the analysis of indirect effects focus on biofuels only, without considering indirect effects of fossil fuels. Many studies conduct no comprehensive sensitivity and uncertainty analysis.

(ii) Input data and assumptions: Many analyses take into account different policies and the use of different start and end-points in time. However, many studies do not take into account the effect of sustainability criteria and national land use policies. Furthermore, many models choose different ratios for biodiesel and ethanol. In addition, some models assume different amounts of harvest levels and feedstock use per MJ of biodiesel as well as the amount and value of byproducts. Assumptions in the demand for different commodities as well as differences in assumed land prices and costs for land conversion can differ between the models. Due to its dynamic nature, iLUC of a specific feedstock can change over time.

(iii) Treatment of carbon stock changes: To determine LUC related GHG emissions different additional carbon stock and emission databases are used to be added to economic modelling. Many models mainly focus on $\mathrm{CO}_{2}$ emissions, without taking into account other GHG emissions highly relevant as potential impacts of agricultural production, like $\mathrm{N}_{2} \mathrm{O}$ and $\mathrm{CH}_{4}$.

\subsection{A Brief Review of the EU iLUC Policy Framework Development}

The topic of iLUC has become a prominent aspect in the debate about biofuels after the definition of ambitious policy targets for the use of bioenergy, mostly in the EU and US transport sector (e.g., [19,26]). Within the EU, the introduction of the RED [17] in 2009 defined a 10\% target for renewable energies in the transport sector, along with a set of sustainability criteria set out in Article 17. The sustainability criteria concern not to obtain the feedstock for biofuels and bioliquids from land with high biodiversity value and high-carbon stock. Biofuels sold in the EU that are to count towards the $10 \%$ target must demonstrate compliance with the sustainability criteria through sustainability certification (compare Figure 4) [17]. It has to be noted, that especially this combination of a target for renewable energy in the transport sector, which created a market or increasing the market volumes for biofuels in EU member states and the definition of sustainability criteria (including a criteria on direct land use change) has led to the complex problem of indirect land use change. The reason is that, whilst the RED has created an additional demand for biofuels and at the same time introduced a criterion, prohibiting the direct conversion of natural land. Since the latter is a criterion that is exclusive for this regulated market of biofuels, it can create spillover effects into other sectors of biomass production [52].

Consequently, different researchers conducted assessments, flagging the high risks for increasing pressure on natural areas because of a policy induced additional demand for biofuels (compare [19,26,27,37]).

In the year 2012, the EC published an impact assessment of different policy options on how to deal with iLUC. The aim of the assessment was to investigate the effectiveness of several policy options aimed at the reduction of iLUC impacts. The following policy options were considered within the assessment:

A. Take no action for the time being, while continuing to monitor.

B. Increase the minimum GHG saving threshold for biofuels.

C. Introduce additional sustainability requirements on certain categories of biofuels.

D. Attribute a quantity of GHG emissions to biofuels reflecting the estimated indirect land-use impact.

E. Limit the contribution from conventional biofuels to the RED targets to current production levels. 


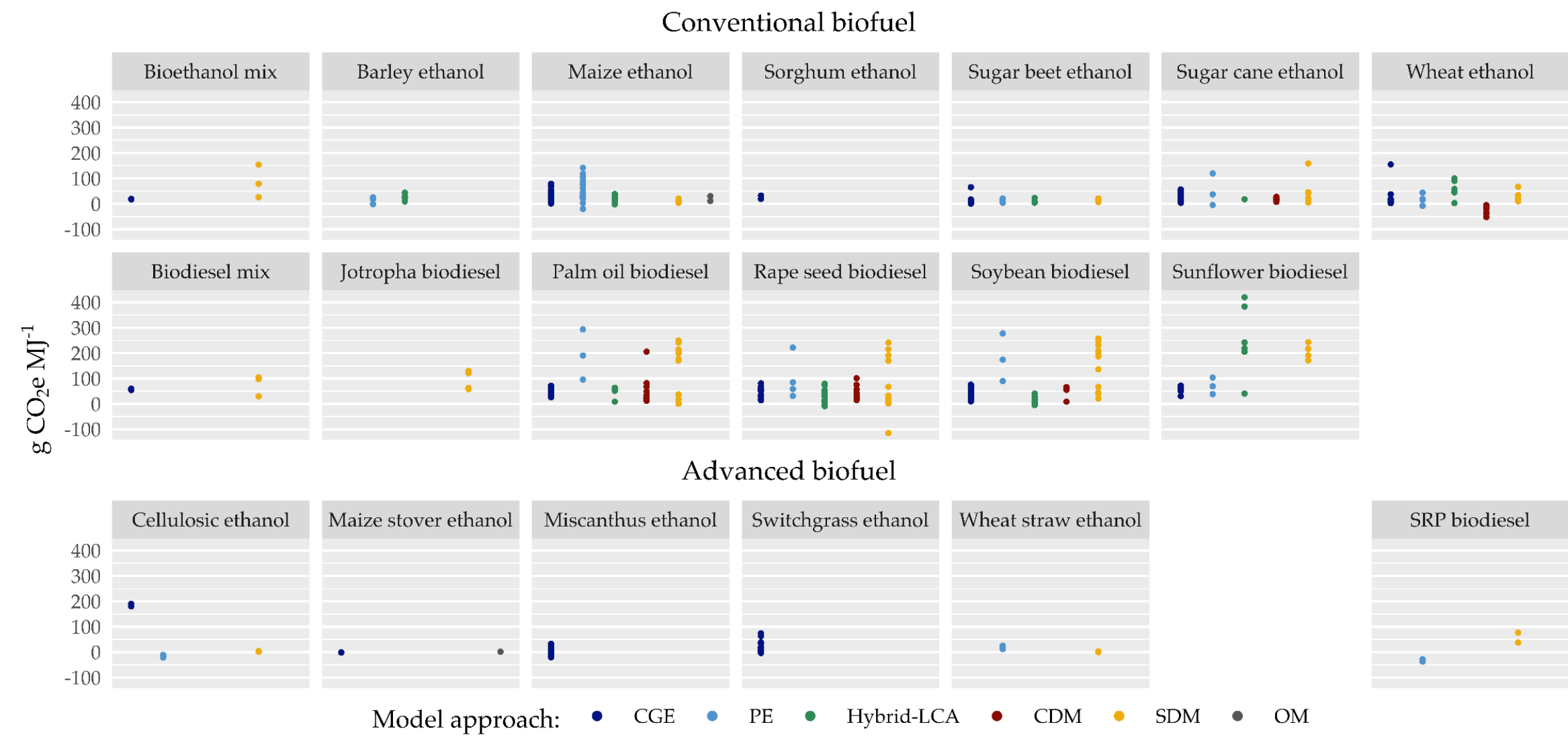

Figure 3. Overview of iLUC emission factors in $\mathrm{g} \mathrm{CO}_{2} \mathrm{e} \mathrm{MJ}{ }^{-1}$ biofuel according to a sample of modelling approaches (CGE: Computable General Equilibrium Model; PE: Partial Equilibrium Model; Hybrid-LCA: Hybrid-Life Cycle Assessment; CDM: Causal-Descriptive Model; SDM: Simplified Deterministic Model; OM: Optimization Model). Conventional biofuels are made from food and feed crops. Advanced biofuels are made from nonfood and nonfeed crops. Every point represents a data value in the literature. 


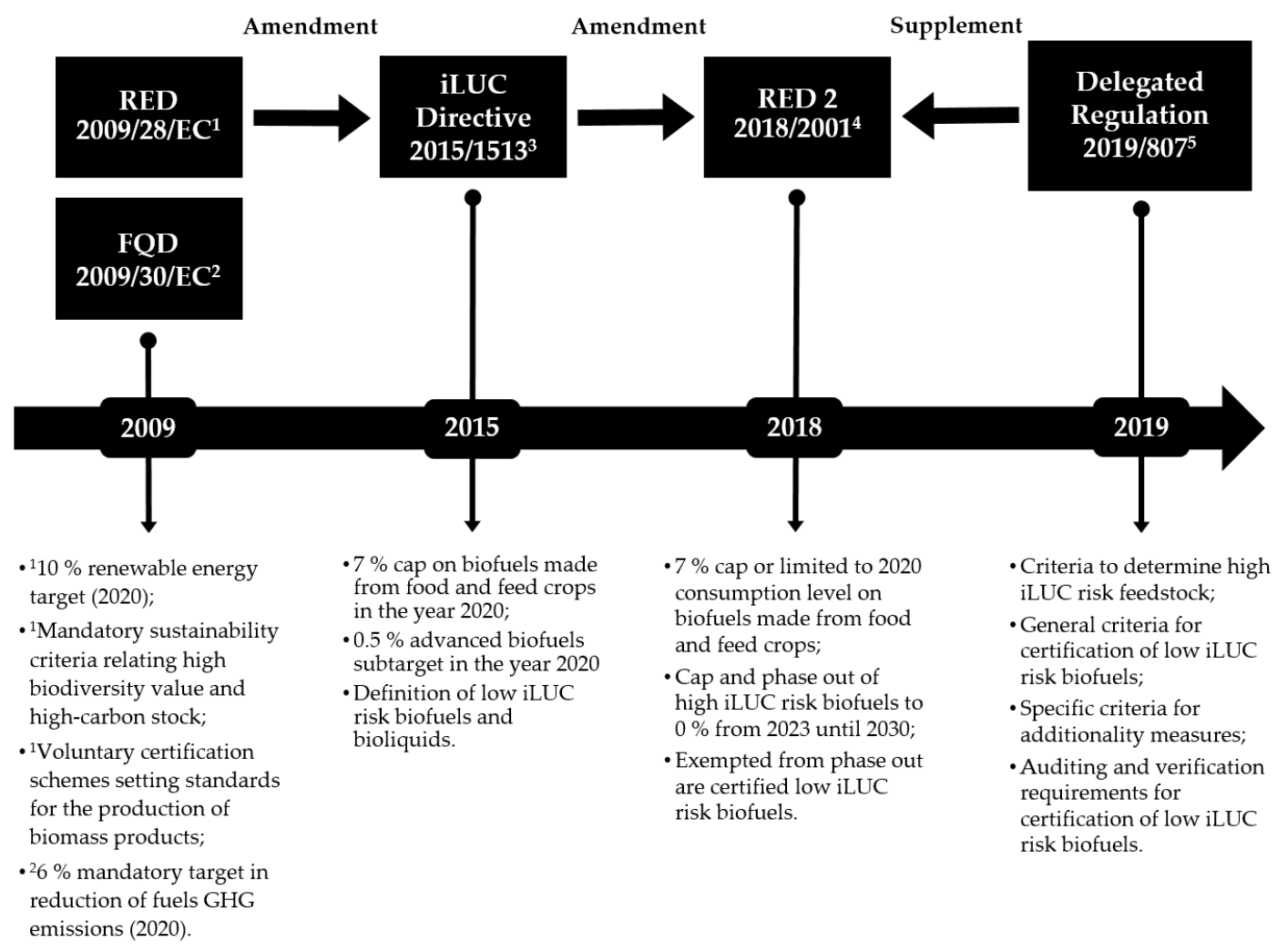

Figure 4. Timeline of the iLUC risk related development of the EU's biofuels policy frame from the year 2009 to 2020 with relevant aspects of each policy for the consideration of low iLUC risks and sustainability certification ( ${ }^{1}$ Renewable Energy Directive (RED) [17]; ${ }^{2}$ Fuel Quality Directive (FQD) [53]; ${ }^{3}$ [25]; ${ }^{4}$ Renewable Energy Directive 2 (RED 2) [21]; ${ }^{5}$ [22]).

The assessment concluded, that a balanced approach based on the option $\mathrm{E}$ accompanied by aspects of the options $\mathrm{B}$ and D, complemented by additional incentives for advanced biofuels, would be the best way to reduce the potential impact of EU biofuel policies [24]. The option B aimed to exclude biofuels with large estimated iLUC emissions. The objective of option D was to incorporate the estimated iLUC emissions values in the reporting of the existing GHG methodology of biofuels. However, the estimated iLUC emissions cannot be determined clearly (compare Section 1.1). The EC rejected the option $\mathrm{C}$ at that time, because criteria and compliance indicators for low iLUC risk practices were insufficiently developed [24].

Based on the results of the impact assessment, the so-called iLUC Directive 2015/1513 was published in the year 2015 [25]. This directive amended the RED and the Directive 98/70/EC [54]. Among other things, it stipulated that the share of energy from biofuels, produced from food and feed crops, should be limited to $7 \%$ of final energy consumption in the transport sector in 2020. Furthermore, the directive presented a methodology for how to calculate the annualised emissions from carbon stock changes caused by LUC. The directive also included a definition of low iLUC risk biofuels and bioliquids. That "means biofuels and bioliquids, the feedstocks of which were produced within schemes which reduce the displacement of production for purposes other than for making biofuels and bioliquids and which were produced in accordance with the sustainability criteria for biofuels and bioliquids set out in Article 17" [25] (p. 14).

In 2018, the Renewable Energy Directive 2 (RED 2) [21] came into force. The RED 2 stipulates the repeal of the RED for the year 2021. Within the RED 2, the 7\% limit for biofuels produced from food or feed crops is maintained. In addition, for biofuels classified as high iLUC risk produced from feedstocks for which a significant expansion of the production area into land with high-carbon stock is observed, e.g., palm oil, a cap and phase-out to $0 \%$ from 2023 to 2030 is set. To determine high iLUC risk biofuels, 
the RED 2 committed the EC to publish a report on the status of worldwide production expansion of relevant feedstock crops by February 2019 (for the report see [55]). However, a biofuel classified as potentially high iLUC risk may be exempted from the phase-out if the biofuels are certified as low iLUC risk in the context of a specific project [21]. In example, biodiesel produced from palm oil can be sold on the European market, if the biodiesel is certified as low iLUC risk. Thus, with the adoption of the RED 2, the focus of the sustainability certification of biofuels has changed to a risk-based approach.

The RED 2 is supplemented by the Commission Delegated Regulation (EU) 2019/807, published in March 2019. The regulation includes criteria for the identification of feedstock with high iLUC risk and general criteria for the certification of biofuels with a low iLUC risk. In addition, the regulation proposes specific criteria for determining so-called additionality measures. The purpose of the additionality measures is to produce an additional amount of biomass without jeopardizing existing users. On the one hand, these include improvements in the efficiency of existing uses, especially the increase in agricultural crop yields. On the other hand, there is the possibility of the planned change in use of previously unused areas. One focus is here on the conversion of abandoned land [22].

\subsection{The Risk-Based Approach with the Focus at iLUC Mitigation for the Sustainability Certification of Biobased Products}

With regard to the model-based calculation of iLUC based risks, as they are described in Section 1.1, several studies concluded that the modelled crop-specific iLUC emissions are not suitable for political policy decisions and should therefore not be included in binding EU regulations [56-58]. First attempts for iLUC risk mitigation were proposed for the assessment of bioenergy for mitigating climate change [59]. Thus, the approach focuses on the risk of iLUC caused by the production of biofuels from a specific feedstock. It should be noted that this approach measures options and strategies to mitigate the impacts of iLUC resulting from an increasing demand for biofuels [15]. Various mitigation measures are proposed in the literature, e.g., intensification and increased efficiency of agricultural production [60]. Finkbeiner [61] suggests shifting the research focus from iLUC impact effects to iLUC mitigation to ensure a scientifically sound assessment of indirect effects. This underlines the change from a regulatory science approach at the global level with high uncertainties due to abstract modelling techniques to the establishment of locally oriented practices to mitigate climate change [62].

Certification is mandatory within the RED and can be an important safeguard mechanism to ensure a certain level of sustainability and to verify compliance with sustainability criteria [63]. Therefore, suitable criteria and indicators for a sustainable development of the BBE are needed [64]. Based on the research mentioned above, a need for a scientifically verified and practically designed low iLUC risk assessment approach for the certification of biobased products can be assumed. We therefore provide a comprehensive overview of potential additionality practices that we expect to reduce the risk of undesirable negative land use changes.

\subsection{Aim and Structure of the Review}

The aim of this review is to identify and develop additionality practices and to identify approaches and how they could possibly be implemented and verified in the sustainability certification of biobased products. Therefore, this study aims to identify methods that are potentially applicable in low iLUC risk certification. Furthermore, this study describes how the low iLUC risk certification approach has evolved in the context of the development of EU iLUC policies and previous approaches of iLUC impact assessment. We intend to show how the EU has adapted the mandatory certification approach of biofuels to the problem of iLUC over the last years and finally introduced the low iLUC risk certification approach. Based on the iLUC policy development, we discuss crucial aspects for the implementation of the identified practices within a robust certification approach, which are in line with recent developments in EU policies dealing with iLUC. In this regard, it is important to note that we do not make recommendations on best management practices for biomass production. We rather aim 
to identify and develop practices and methods and how the certification of biomass with low iLUC risk could be implemented in sustainability certification practices.

We started by presenting the relevance of iLUC, accompanied by the presentation of activities to quantify the iLUC effects of biofuels and the political debate on how to deal with iLUC within the EU. In the next steps, we will describe our approach for the selection of relevant literature. Subsequently, we will present potential additionality practices and methodological proposals for a low iLUC risk assessment and certification practice. This is followed by a discussion on whether, and how, the identified additionality practices could be implemented and verified in the sustainability certification of biobased products. Furthermore, we present limitations of the low iLUC risk certification approach. We conclude the review with a short conclusion and an outlook on further research needs in the field of low iLUC risk biomass certification.

\section{Materials and Methods}

\subsection{Approach for the Selection of the Reviewed Literature}

This paper presents a comprehensive analysis of literature dealing with additionality practices and methodological proposals for their assessment in the sustainability certification of biobased products. The keywords shown in Table 1 have been used for the literature search. For a better overview, the keywords are grouped in three different thematic blocks.

Table 1. Keywords for the literature review grouped into three thematic blocks.

\begin{tabular}{|c|c|c|}
\hline Block 1 & Block 2 & Block 3 \\
\hline "iluc risk" & biomass & certify * \\
\hline "indirect land use change risk" & bioenergy * & assess * \\
\hline "low indirect impact" & biofuel * & indicat * \\
\hline & biobased * & method* \\
\hline & bio-base * & \\
\hline
\end{tabular}

The asterisk $\left(^{*}\right)$ is used to find variations with fewer search terms. For example, certif* is used to find literature including either certification, certify, certified, etc. or all variations matching this term.

Selection criteria are defined to ensure comparability of results. Therefore, the literature selection followed the subsequent requirements:

- Published recently (between 2008 and 2020);

- Focus on low iLUC risk assessment;

- Published in a peer-reviewed scientific journal.

As there are several, relevant studies dealing with additionality practices and assessment methodologies that have not been published in peer-reviewed journals, we made some exceptions and partly extended the review. This concerns mainly technical reports and indicator sets of certification approaches dealing with low iLUC risk practices. The exceptions are made to provide a comprehensive overview of the full range of research and current practice in the field of additionality practices potentially suitable for certification. The studies selected must meet the following criteria:

- Be written in English;

- Are publicly available;

- Include descriptions of a concept for a low iLUC risk assessment framework or certification approach.

\subsection{Identification and Development of Additionality Practices}

Our review consists of two parts. In the first part, we derive potential additionality practices by analysing key drivers and parameters of relevant iLUC modelling approaches. The analysis is 
based on a study conducted for the STAR-ProBio project [65]. In the second part, we identify potential additionality practices by examining existing low iLUC risk assessment approaches. We analyse indicator sets of existing certification approaches and studies dealing with low iLUC risk assessment. Preferably, assessment studies dealing with practices on the project level are examined. The reason for this is that the focus of our research is on additionality practices for the certification of biobased products. However, in order to get a comprehensive overview of the practices developed for low iLUC risk assessment, other application levels are also considered. It is important for the analysis of the identified additionality practices that a detailed description as well as a methodology for the quantification of low iLUC risk biomass is included in the investigated studies.

\subsection{Studies Reviewed and Studies Excluded from the Review Dealing with Low iLUC Risk Assessment Frameworks}

Applying the selection criteria mentioned above, we analysed the studies listed in Table A1.

The following studies, which deal with low iLUC risks, were not analysed in detail in our review. For each study, we provide short explanations why we did not analyse the study in detail. The advisory company Ernst \& Young identified a number of iLUC reduction practices [66]. However, the practices are described too briefly for our purposes. Furthermore, a conceptual assessment framework is missing. Wicke et al. [15] propose several iLUC mitigation strategies, from which Wicke et al. [67] derives so-called iLUC prevention measures. Neither study is analysed in detail in our review. The reason for this is that we have reviewed the study by Brinkman et al. [68]. Brinkman et al. proposes a comprehensive quantification methodology to assess the effect of the iLUC mitigation measures mentioned in both studies. Another study that we have excluded from our analysis is an assessment of biomethane with low iLUC risk carried out by Peters et al. [69]. We have not examined the study because the methodology is based on the methodologies developed by Peters et al. [70], which we have examined in detail. El Takriti et al. [71] reviewed relevant literature. We have not analysed the review in detail, as most of the studies examined by El Takriti et al., are already part of our review. Woltjer et al. [35] provide a comprehensive overview of research activities on the certification of low iLUC risk biofuels and the main mitigation options, which we already analysed in detail for our report. Fritsche et al. [72] discuss several options for reducing the iLUC risk in a literature review. The review includes options that we have already presented in our review. Furthermore, we did not analyse the options reviewed by Fritsche et al. [16] in detail, because these are not part of a conceptualized framework for iLUC reduction.

\section{Results-Potential Additionality Practices for the Certification of Biobased Products}

\subsection{Overview of Additionality Practices Identified in the Reviewed Literature}

Table 2 provides an overview of the additionality practices identified in the reviewed literature. Three practices can be found in most studies. These are (i) increasing agricultural crop yields, (ii) growing biomass on unused land, and (iii) improving the integration of byproducts, waste, and residues into the production chain. Table 2 does, furthermore, include two additional approaches, (i) reduction in biomass losses and (ii) improvements in livestock production efficiencies, analysed by only a few studies.

In the following sections, we describe each identified additionality practice in general and potential approaches for their implementation and verification in the sustainability certification of low iLUC risk biobased products. Figure 5 gives an overview about the additionality practices and the identified potential verification methods. 
Table 2. Overview of identified potential additionality practices from the reviewed studies dealing with low iLUC risk assessment frameworks.

\begin{tabular}{|c|c|c|c|c|c|c|c|c|c|c|c|}
\hline & $\begin{array}{c}\text { Better } \\
\text { Biomass [73] }\end{array}$ & $\begin{array}{l}\text { Brander } \\
\text { et al. [74] }\end{array}$ & $\begin{array}{l}\text { Brinkman } \\
\text { et al. [68] }\end{array}$ & $\begin{array}{l}\text { Dehue } \\
\text { et al. [75] }\end{array}$ & $\begin{array}{c}\text { GBEP }^{1} \\
{[76]}\end{array}$ & $\begin{array}{c}\text { Malins } \\
\text { [77] }\end{array}$ & $\begin{array}{l}\text { Peters } \\
\text { et al. [70] }\end{array}$ & $\begin{array}{c}\text { RSB }^{2} \\
{[78]}\end{array}$ & $\begin{array}{l}\text { Spöttle } \\
\text { et al. [79] }\end{array}$ & $\begin{array}{c}\text { Van de Staaij } \\
\text { et al. [80] }\end{array}$ & $\begin{array}{c}\text { Van de Staaij } \\
\text { et al. [81] }\end{array}$ \\
\hline Increased yield $^{3}$ & $x$ & $x$ & $x$ & $x$ & $x$ & $x$ & $x$ & $x$ & & $x$ & \\
\hline Unused land ${ }^{4}$ & $\mathrm{X}$ & $\mathrm{X}$ & $x$ & $x$ & $x$ & $x$ & $x$ & $x$ & & $x$ & $x$ \\
\hline Chain integration ${ }^{5}$ & $x$ & & $x$ & $x$ & $x$ & $x$ & & $x$ & $x$ & $x$ & \\
\hline Loss reduction ${ }^{6}$ & & $x$ & $x$ & & & & & & & & \\
\hline Livestock efficiencies ${ }^{7}$ & & & $x$ & & & & & & & & \\
\hline
\end{tabular}

${ }^{1}$ Global Bioenergy Partnership; ${ }^{2}$ Roundtable on Sustainable Biomaterials; ${ }^{3}$ Increased agricultural crop yield; ${ }^{4}$ Biomass cultivation on unused land; ${ }^{5}$ Improved production chain integration of byproducts, waste, and residues; ${ }^{6}$ Reduction in biomass losses; ${ }^{7}$ Improvements in livestock production efficiencies.

\section{Additionality} practices:

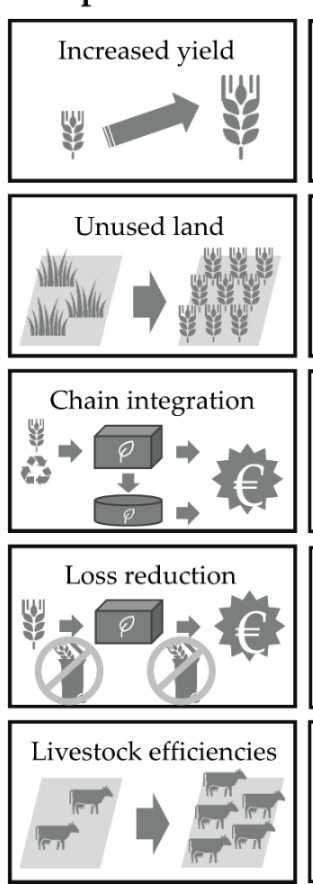

Potential methods for implementation and verification of identified additionality practices in certification practice:

\begin{tabular}{|c|}
\hline $\begin{array}{c}\text { Method I. } \\
\text { Historical yields linear } \\
\text { trendline reference }\end{array}$ \\
\hline $\begin{array}{c}\text { Method VI. } \\
\text { Actual amount of } \\
\text { harvested feedstock }\end{array}$ \\
\hline $\begin{array}{c}\text { Method VIII. } \\
\text { Establishing a positive } \\
\text { list of EoL products }\end{array}$ \\
\hline $\begin{array}{c}\text { Method XIII. } \\
\text { Regional low iLUC risk } \\
\text { potential (loss reduction) }\end{array}$ \\
\hline $\begin{array}{c}\text { Method XIV. } \\
\text { Regional low iLUC } \\
\text { risk potential } \\
\text { (livestock efficiencies) }\end{array}$ \\
\hline
\end{tabular}

\begin{tabular}{|c|c|c|c|}
\hline $\begin{array}{c}\text { Method II. } \\
\text { Dynamic baseline yield } \\
\text { scenario }\end{array}$ & $\begin{array}{c}\text { Method III. } \\
\text { Regional low iLUC risk } \\
\text { potential (increased yield) }\end{array}$ & $\begin{array}{l}\text { Method IV. } \\
\text { Crediting } \\
\text { implementation } \\
\text { and outcome }\end{array}$ & $\begin{array}{l}\text { Method V. } \\
\text { Moving trendline yield }\end{array}$ \\
\hline $\begin{array}{c}\text { Method VII. } \\
\text { Regional low iLUC risk } \\
\text { potential (unused land) }\end{array}$ & & & \\
\hline $\begin{array}{c}\text { Method IX. } \\
\text { Input-output-analysis } \\
\text { and an average } \\
\text { conversion rate }\end{array}$ & $\begin{array}{l}\text { Method X. } \\
\text { Ethanol from } \\
\text { sugarcane-cattle } \\
\text { integration }\end{array}$ & $\begin{array}{l}\text { Method XI. } \\
\text { Theoretical, sustainable } \\
\text { and low iLUC potential }\end{array}$ & $\begin{array}{l}\text { Method XII. } \\
\text { Regional low iLUC } \\
\text { risk potential } \\
\text { (chain integration) }\end{array}$ \\
\hline
\end{tabular}

Figure 5. Identified additionality practices and potential approaches for implementation and verification in sustainability certification of low iLUC risk biobased products. 


\subsection{Increased Agricultural Crop Yield}

\subsubsection{General Description}

The basic rationale behind the concept of increasing agricultural productivity is to improve the overall efficiency of an existing area of arable land without unplanned expansion to other, currently unmanaged areas $[68,70,80]$. Table 2 provides an overview of the studies examined, which propose a methodology for operationalising agricultural yield enhancement potentially applicable in certification practice. Several studies provide a detailed description and methodology for quantifying low iLUC risk biomass. Details of the studies analysed are given in Table A1. In addition, some authors highlight multicropping systems as a specific promising yield improvement measure for the production of biomass with low iLUC risk $[70,77,78]$. It should be noted that we do not make recommendations for agricultural management practices to increase agricultural yields. Instead, this review aims to provide a general overview on the debate and existing approaches on how additionality practices could be robustly implemented in the sustainability certification of biobased products.

3.2.2. Approaches to Determine the Amount of Low iLUC Risk Biomass from Increased Agricultural Crop Yield

\section{Method I. Historical Yields Linear Trendline Reference of One Farm or Group of Farms}

The linear trendline reference method for historical yields, proposed by Peters et al. [70] is a simplified approach, which compares the actual yield of a producer with a reference or baseline yield. The reference scenario is determined using the historical yields of a given crop over the last 10 years of a farm or group of farms proposed for certification and expressed by a linear trendline reference. A reference point is determined with these trendline yields. As a result, each yield above the reference point is classified as having a low iLUC risk. For example, a producer has documented the yield data for maize production for each year from 2010-2019. By applying the method of least squares, the linear trendline reference is calculated. Therefore, the farm determines the beginning of the linear trendline 10 years before (year 2010) proposed to produce certified low iLUC risk maize (e.g., $3.8107 \mathrm{t} \mathrm{ha}^{-1}$ ) and added the annual yield growth of the same period (e.g., $0.1004 \mathrm{t} \mathrm{ha}^{-1} \mathrm{a}^{-1}$ ), multiplied by the year, for which the trendline yield has to be calculated. In our case, this is year number 10 for the year 2019 . The reference point for the year 2019 is then simply calculated by the equation: $\mathrm{Y}_{\text {ref,2019 }}=3.8107 \mathrm{tha} \mathrm{t}^{-1}$ $+0.1004 \mathrm{tha}^{-1} \mathrm{a}^{-1} \times 10=4.8 \mathrm{tha}^{-1}$. Any maize yield above $4.8 \mathrm{t} \mathrm{ha}^{-1}$ is low iLUC risk [70]. The potential advantages and disadvantages of this approach could be summarised on the basis of the results of the STAR-ProBio project [82], as in Table 3. 
Table 3. Potential advantages and disadvantages of the Method I, II, III, IV, and V.

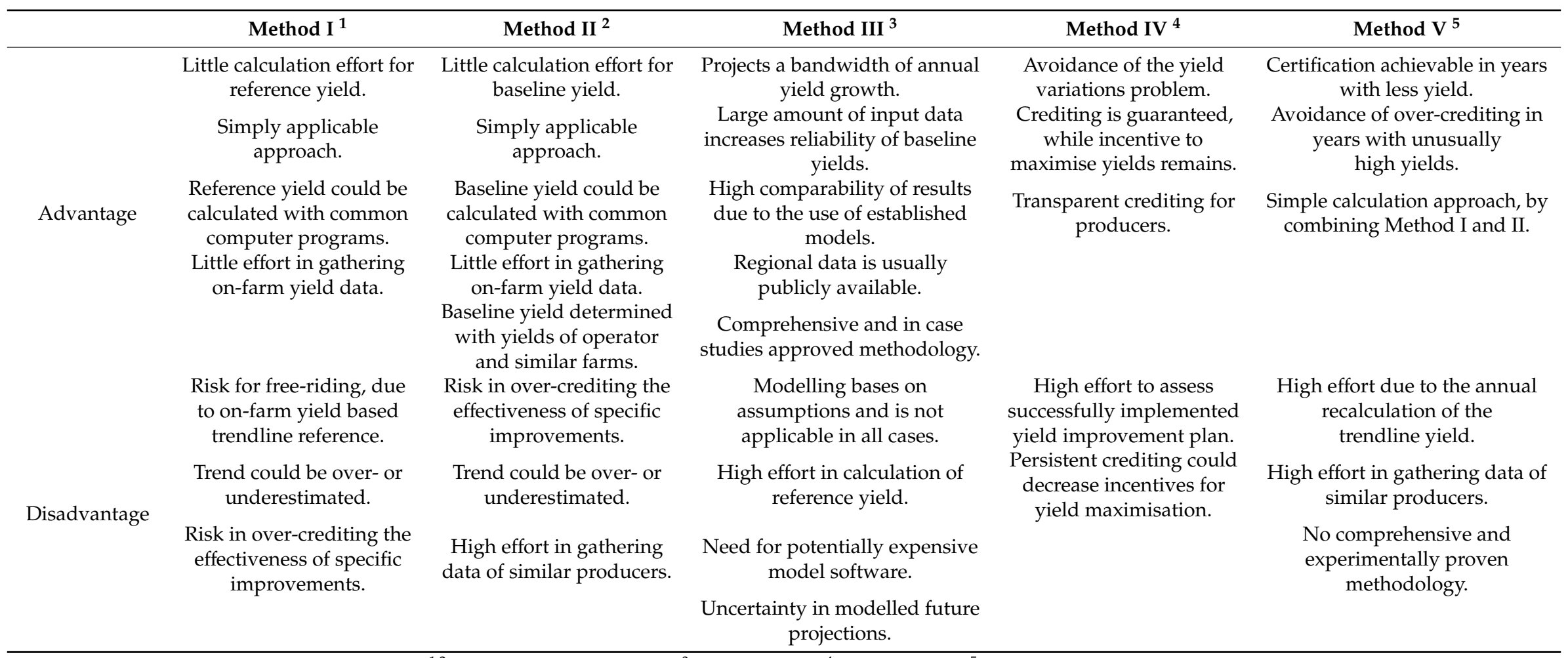

1,2 Partly taken from $[77,80,82],{ }^{3}$ taken from $[82],{ }^{4}$ taken from $[77],{ }^{5}$ taken from $[82,83]$. 
Method II. Dynamic Baseline Yield Scenario

The methodology of the dynamic baseline yield scenario is an extension of Method I, considering additionally the historical yields of comparable producers in a specified geographical area [84]. Van de Staaij et al. [80] present several criteria to determine similar producers or farms. The Roundtable on Sustainable Biomaterials (RSB) proposes a method to calculate the dynamic baseline yield and the amount of low iLUC risk biomass resulting from its application. For example, the baseline scenario is determined by deducting the average annual maize yield growth for similar farms in a region of $3.51 \mathrm{tha}^{-1}$ from the actual maize yield calculated with the yields of the last 5 years of the farm proposed to be certified of $3.8 \mathrm{tha}^{-1}$, multiplied by the maize cultivation area of 80 ha. This results in $23.2 \mathrm{t}$ biomass, certifiable as low iLUC risk maize [78]. However, the methodology presented by the RSB is based on the Low Indirect Impact Biofuel (LIIB) methodology developed by Van de Staaij et al. [80]. According to Van de Staaij et al. [80], the methodology is developed for the determination of biofuels with a low risk of unwanted indirect impacts. It is especially conceptualised as an independent module, which can be added to existing certification schemes and biofuel policies [80]. Based on the analysis of the STAR-ProBio project [82], the potential advantages and disadvantages of this approach could be summarised as in Table 3.

\section{Method III. Regional Low iLUC Risk Potential from Above Baseline Yield Increase}

The aim of this method is to determine how much additional biofuel feedstock can be produced from above baseline yield increases to determine the low iLUC risk potential in a region. The method models regional data and calculates the biomass production potential on the basis of this data. This is followed by a comparison of the low iLUC risk potential with the biofuel feedstock target for this region [68]. For example, in a case study conducted by Brinkman et al. [85], the above baseline yield increase of maize for bioethanol production in Hungary was assessed. The authors determined a baseline scenario based on a reference scenario from the CGE model MIRAGE (compare Figure 2). To determine the above baseline yield increase, a scenario analysis was conducted, including a low, medium, and high scenario with different assumptions of yield increase for Hungary. Possible advantages and disadvantages of this approach could be summarised on the basis of the results of the STAR-ProBio project [82] as in Table 3.

\subsubsection{Extending the Previously Mentioned Approaches in Order to Address the Issue of} Yield Variations

Various difficulties can arise in implementing robust certification approaches for low iLUC risk biomass assessment. One of the biggest challenges is yield variations, mainly due to varying weather conditions. These annual yield fluctuations in a given region for a given producer may be greater than the yield increase resulting from the implementation of a yield improvement measure [77]. This may therefore influence the comparison of the actual yield with a baseline yield as proposed by the above methods. The result may be overestimation in years with favourable weather conditions and underestimation in years with unfavourable weather conditions [77,84]. In conclusion, an approach based only on a simple statistical trend might not be appropriate for the development of a robust low iLUC risk certification of increased crop yield [82].

\section{Method IV. Crediting Project Implementation and Outcome}

Malins [77] proposes an approach that combines the crediting of a project against the expected project benefits as a result of the successful implementation of a yield improvement plan and the actual yield results. Hence, this approach requires the implementation of a yield improvement plan that allows the project to demonstrate reasonable expectations of yield growth. According to Malins [77] the credit for project implementation or outcome could be set at a minimum of $30 \%$, each. However, the author points out that the balance between the two elements must be chosen in such a way that there 
are sufficient incentives for both credit systems. Based on the results of Malins [77], Table 3 summarises the potential advantages and disadvantages of this approach.

Method V. Moving Trendline Yield

According to the moving trendline yield approach, proposed by Searle [83], biomass with low iLUC risk is the result of the difference between the trendline yield calculated for each year and a dynamic baseline yield. The latter takes into account the yields of similar producers within a geographical area (compare Method II). The trendline yield is calculated using the observed yields in all years since the producer was certified. The trendline moves each year in relation to the actual observed yields. For example, the trendline yield for the first year after certification is based on the yields of the years zero and one. The trendline yield for the second year after certification is based on the yields of the years zero, one, and two, etc. The potential advantages and disadvantages could be summarized as in Table 3, based on the results of Searle [83] and the STAR-ProBio project [82].

\subsection{Biomass Cultivation on Unused Land}

\subsubsection{General Description}

This concept is based on the idea of taking an unused plot of land into agricultural production to provide additional biomass, without intensification on existing agricultural land and without expanding and replacing existing biomass users $[70,77,80]$. Table 2 provides an overview of the studies reviewed that deal with this additionality practice. This is complemented by Table A1, which describes in more detail the studies examined, which propose methods for quantifying low risk iLUC biomass grown on previously unused land.

\subsubsection{Definition of Unused Land and Unused Land Categories}

For the certification of biomass produced on formerly unused land, a robust definition and proof that the land is not used is very important [70]. If the term unused land is not clearly defined, biodiversity loss or high GHG emissions could be the consequence, as land with high biodiversity value or high-carbon stock could be converted [75]. The definition introduced by the EC [22] plays an important role for the certification of low iLUC biofuels within the EU sustainability framework for biobased products [82]. According to Peters et al. [70], unused land is land that has not been used to provide services for a certain period of time in the past. The RSB [78] considers several other specific cases for identifying unused land, e.g., avoiding the use of areas with shifting cultivation.

There are several specifications of the concept of unused land. A list with descriptions of categories of unused land is presented by the STAR-ProBio project [82]. Examples are abandoned agricultural land as well as degraded, marginal, and set-aside land $[15,86]$.

\subsubsection{Additional Criteria to Demonstrate Unused Land Status}

A site-specific investigation [70] could be carried out to identify a suitable plot of land. This could include the following verification activities:

- The review of regulatory criteria (e.g., legal and traditional and/or customary rights) [70];

- The verification of land cover and use criteria (e.g., low biodiversity value and lowcarbon stock) [70];

- Verifying whether the land was previously used for provisioning services (e.g., food, timber, or fibre) [78];

- The verification of information on the location, size, actual use, and suitability for feedstock cultivation [68].

In addition, Peters et al. [70] propose to conduct an independent on-site audit to verify the results of the site-specific investigation activities listed above. Dehue et al. [75] present the concept of 
Responsible Cultivation Areas (RCA). This is a detailed practical methodology for identifying land suitable for the production of low iLUC risk biomass. The RCA is complemented by the Unused Land Guidance proposed by Van de Staaij et al. [81]. This guidance is developed for a practical and operational ex-post evaluation of unused land parcels. According to the LIIB Methodology, an unused plot of land can be identified, if unused land with similar quality characteristics can be identified within the same region [80]. Malins [77] distinguishes between regions of agricultural decline and expansion with regard to the selection of suitable unused land.

3.3.4. Approaches to Determine the Amount of Low iLUC Risk Biomass from Biomass Cultivation on Unused Land

Method VI. Determination of the Actual Amount of Harvested Feedstock

This approach takes into account the actual amount of feedstock harvested at the site that could be identified as unused land. Based on the actual yields and the size of the previously unused area, the amount of biomass with a low iLUC risk can be calculated $[78,80]$. For example, if the actual maize yield of a farm proposed for certification is $4.2 \mathrm{tha}^{-1}$ on the identified unused plot of land and the size of the plot is 100 ha, then $420 \mathrm{t}$ of maize can be certified as low iLUC risk biomass [78]. Potential advantages and disadvantages of this approach could be summarised as in Table 4, based on results of the STAR-ProBio project [82].

Table 4. Potential advantages and disadvantages of Method VI and VII.

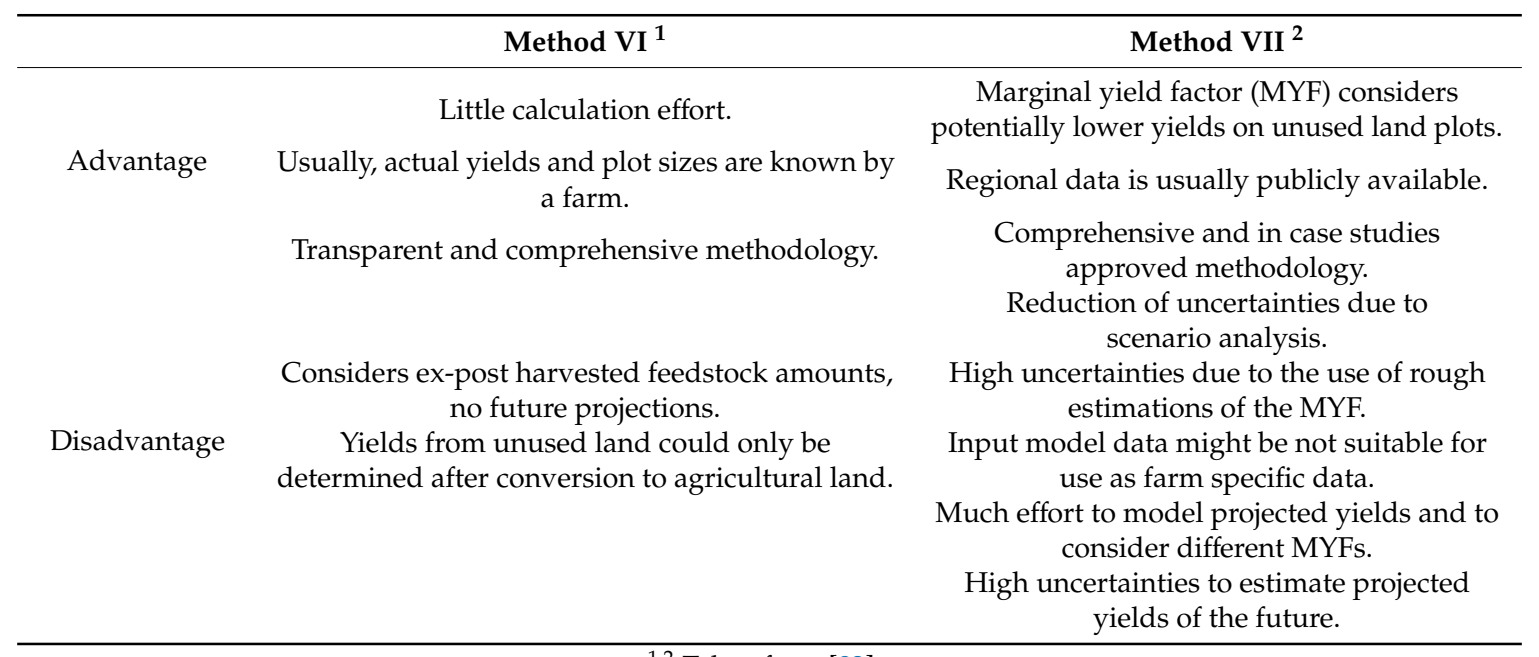

${ }^{1,2}$ Taken from [82].

Method VII. Regional Low iLUC Risk Potential from the Calculation with Projected Yields and a Marginal Yield Factor

This approach determines the low iLUC risk potential of a given region when land previously unused is taken into account, by considering modelled crop yields predicted for the future. The approach introduces a marginal yield factor (MYF), which assumes a lower productivity of underutilized land compared to the average agricultural land [68]. For example, in a case study of rapeseed biodiesel in Eastern Romania conducted by Brinkman et al. [87], the baseline of available abandoned land is set to zero hectare. This is compared with a low ( $>50$ ha), medium ( $>20$ ha), and high (All) scenario dealing with different sizes of land available for biomass production. Furthermore, a MYF for the low $(50 \%)$, medium $(75 \%)$, and high $(99 \%)$ scenario is assumed to determine the low iLUC risk potential from the cultivation of abandoned land. Possible advantages and disadvantages of an approach based on forecasted yields and a MYF might be summarized as in Table 4, taken from the STAR-ProBio project [82]. 


\subsection{Improved Production Chain Integration of Byproducts, Waste, and Residues}

\subsubsection{General Description}

Improvements in the integration of byproducts, waste, or residues in the supply chain deal on the one hand with an increase in the amount of biobased products manufactured directly from existing materials that are actually not or inefficiently used as feedstock. On the other hand, byproducts, waste, or residues could be integrated into other land based production systems, e.g., for livestock feeding, to use existing arable land for biobased products feedstock production. Table 2 provides an overview of the reviewed studies that deal with this additionality practice. Table A1 includes characteristics of the studies reviewed that propose a methodology to quantify the amount of low iLUC risk biomass integrating byproducts, waste, or residues. A clear and robust definition of the terms byproduct, waste, and residue is very important. Starting from the definition of material streams, several authors propose a detailed assessment of alternative uses and possible effects of displacement of other uses and application in the production of biobased products [76,78-80].

3.4.2. Approaches to Determine the Amount of Low iLUC Risk Biomass from Improved Production Chain Integration

Method VIII. Quantification of LIIB Compliant Biofuels by Establishment of a Positive List Regarding Partial Use of End-of-Life (EoL) Products

This approach is part of the LIIB Methodology [80]. Waste and residue (EoL product) streams eligible for low iLUC risk certification can be identified by a multistep approach. Based on the definition of whether a material is a waste or residue in a particular region, the so-called feedstock-region combination, the owner of the certification scheme publishes a periodically updated positive list including this feedstock-region combination. In the case that only a share (\%) of the total annual production of the EoL product stream can be included in the positive list, only this part can be classified as low iLUC risk [80]. If, for example, in a certain region $20 \%$ of wheat straw is already used for other purposes, the remaining $80 \%$ of the straw could be eligible as low iLUC risk feedstock for biobased products [79]. Possible advantages and disadvantages of this approach could be summarised as in Table 5, which is partly based on the results of the STAR-ProBio project [82].

Method IX. Quantification of Low iLUC Risk Biofuels and Biomaterials from Waste and Residues with an Input-Output-Analysis and an Average Conversion Rate

The methodology presented by the RSB [78] is based on the LIIB Methodology [80]. A waste or residue stream must meet several criteria to be considered for low iLUC risk certification. This can be, for example, the disposal by landfill or incineration of the waste or residue within a certain region. In contrast to the LIIB Methodology, the RSB does not require the establishment of a positive list for a feedstock-region combination. Instead, an input-output-analysis is performed. This analysis takes into account the identified low iLUC risk waste or residue as input of the production process. As output, the amount of low iLUC risk biofuel or biomaterial produced with the input is considered. Furthermore, an average conversion rate is determined on the basis of this input-output analysis [78]. If, for example, the amount of low iLUC risk wheat straw for bioethanol production in a certain year is $5000 \mathrm{t}$ and the average conversion rate of wheat straw to ethanol is 0.84 , the amount of $4200 t$ of the wheat straw based ethanol could be certified as low iLUC risk [78]. Potential advantages and disadvantages of this approach could be summarised as in Table 5, partly taken from the STAR-ProBio project [82]. 
Table 5. Potential advantages and disadvantages of Method VIII, IX, X, XI, and XII.

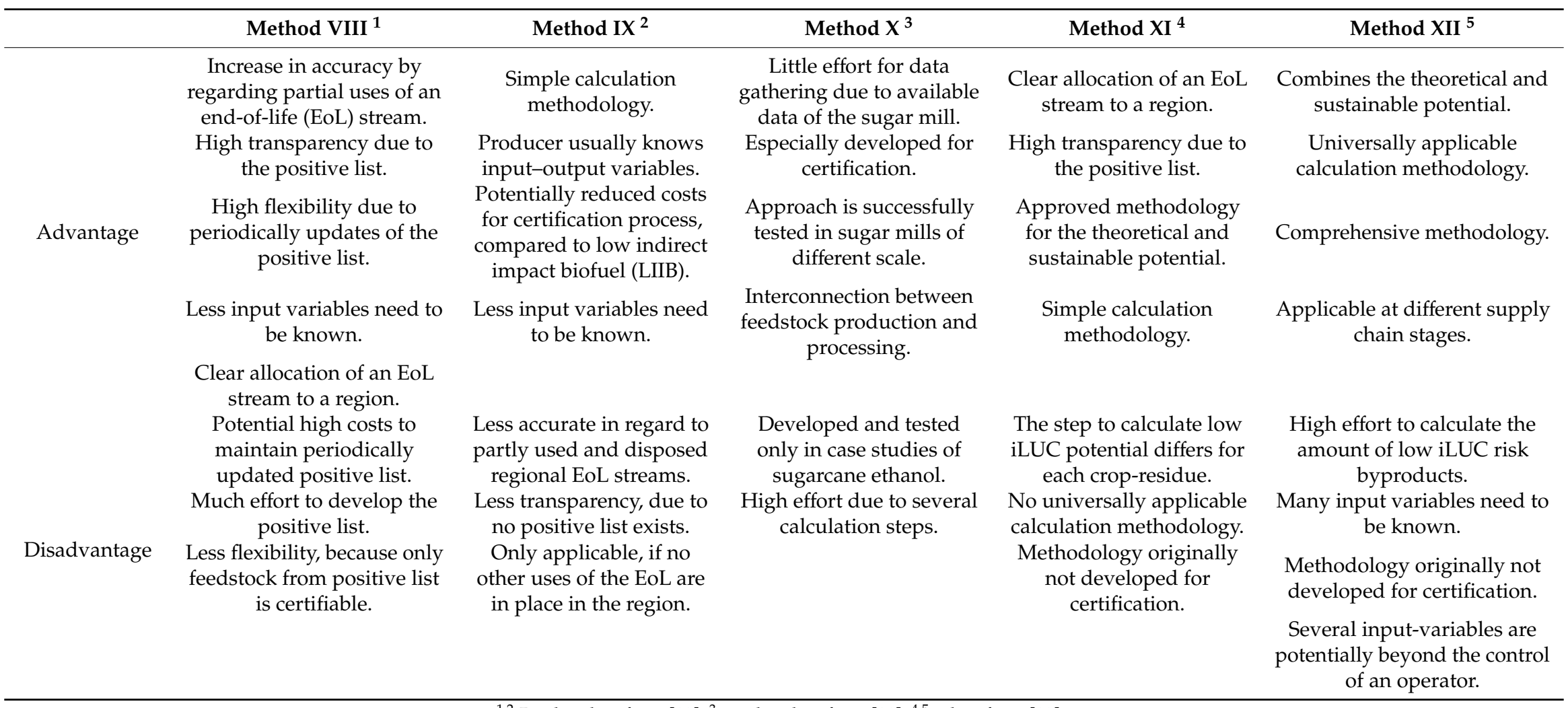

${ }^{1,2}$ Partly taken from $[82],{ }^{3}$ partly taken from $[80], 4,5$ taken from [82]. 
Method X. Quantification of LIIB Compliant Ethanol from Sugarcane-Cattle Integration Projects

The LIIB Methodology proposes an approach specifically developed for the iLUC risk assessment of sugarcane-cattle integration projects. It considers the integration of residues from sugarcane mills as feed for cattle production. As a result, less land is needed to produce a given amount of feed for the cattle. This land is called equivalent "ILUC avoided" area. Therefore, the annual amount of bioethanol produced from feedstock cultivated on this land can be certified with a low iLUC risk [80]. For example, in a case study conducted in the year 2010, the Estiva sugarcane mill in Brazil produced 144,860 $\mathrm{m}^{3}$ of ethanol and processed 26,472 ha of sugarcane fields. By application of the sugarcane-cattle integration project proposed by Van de Staaij et al. [80], the mill produced $84,865 \mathrm{~m}^{3}$ LIIB compliant ethanol on 12,126 ha equivalent iLUC avoided area [80]. Possible advantages and disadvantages of this approach might be summarised as in Table 5, partly taken from Van de Staaij et al. [80].

Method XI. Estimation of the Theoretical, Sustainable, and Low iLUC Potential at Regional Level

Similar to Method VIII, this approach is based on the LIIB Methodology [80]. Therefore, the approach requires the development of a positive list including the feedstock-region combination of a specific waste or residue stream within a specific region. However, the method differs from the Method VIII as it is designed to assess the low iLUC potential of waste and residue streams at regional level [79]. Spöttle et al. [79] propose a multistep approach based on a study presented by Scarlat et al. [88]. It follows the steps from theoretical to sustainable and low iLUC potential [79]. For example, in a case study for the assessment of the low iLUC potential of cereal straw in EU member states, the theoretical straw potential was determined by the application of the straw to crop yield ratio. After that, this theoretical straw potential was multiplied with the sustainable removal rate in percentage of straw to estimate the sustainable straw potential. To determine the low iLUC potential for straw, alternative uses of the straw, e.g., for animal bedding or fodder in the livestock sector were deducted from the sustainable straw potential. Thus, e.g., for Germany the sustainable straw potential was estimated with $11.6 \mathrm{Mt}$, the alternative uses with $5.6 \mathrm{Mt}$, and the resulting low iLUC potential with 6.0 Mt. [79]. Possible advantages and disadvantages of this method could be summarised as in Table 5 based on results of the STAR-ProBio project [82].

\section{Method XII. Regional Low iLUC Risk Potential from Improved Byproducts Integration}

The ILUC Prevention project developed a methodology for the regional assessment of the low iLUC risk potential as a result of the application of improvements in the integration of coproducts in the production chain [68]. To comply with the EU Waste Framework Directive 2008/98/EC [89], we propose to use the term byproduct instead of coproduct. The assessment of improved byproducts integration could be realised by an inventory analysis of the byproducts, followed by an assessment of the potential byproducts use and replacement rate of other products [68]. For example, in a case study region in Indonesia, van der Laan et al. [90] evaluated the low iLUC risk potential for the integration of oil palm trunks (OPTs), a byproduct of the palm oil production. The basic idea behind this concept is that OPT plywood could be used as an alternative to softwood from pulp plantations. The result is that in the low (2000 ha), medium (10,000 ha), and high (18,000 ha) scenarios, OPTs could be harvested on a certain proportion of the oil palm plantation area for the production of OPT plywood and then the area could be replanted with oil palms. Potential advantages and disadvantages for determining the regional low iLUC risk potential through improved integration of byproducts could be summarized as in Table 5, based on results of the STAR-ProBio project [82].

\subsection{Reduction in Biomass Losses}

\subsubsection{General Description}

The reduction of biomass losses aims at increasing the efficiency of a product value chain in order to provide additional biomass for the production of biofuels or biomaterials. The additional 
biomass resulting from the reduction of losses could be used directly for the production of biobased products [67]. Table 2 shows two assessment frameworks that address this additionality practice. Table A1 presents characteristics of the reviewed studies that address this additionality practice.

3.5.2. Approach to Determine the Amount of Low iLUC Risk Biomass from the Reduction in Biomass Losses

Method XIII. Regional Low iLUC Risk Potential from Reductions in Biomass Losses

Brinkman et al. [68] present a methodology developed to determine the iLUC risk and to assess the biomass production potential from the reduction of biomass losses within a given region. It is based on the modelling of regional data and allows future projections as a result. The method focuses specifically on the reduction of food waste and food losses in the supply chain. For example, in a case study conducted in a region in Eastern Romania, Brinkman et al. [87] assessed the low iLUC risk potential through reduced agricultural losses. For the baseline scenario, the authors assumed no change in losses. In contrast, the authors defined three different scenarios to estimate the potential under changed conditions. The calculation took into account the assumed mass fractions of the losses in the year 2020. Potential advantages and disadvantages of this method could be summarised as in Table 6.

Table 6. Potential advantages and disadvantages of Method XIII.

\begin{tabular}{cc}
\hline Advantage & Disadvantage \\
\hline Comprehensive methodology. & $\begin{array}{c}\text { Modelling based on assumptions and is therefore not } \\
\text { applicable in all cases. }\end{array}$ \\
In case studies approved methodology. & $\begin{array}{c}\text { Possibly high effort to collect disaggregated data on } \\
\text { each stage of the supply chain. } \\
\text { Methodology originally not developed for } \\
\text { certification. }\end{array}$ \\
Applicable at different supply chain stages. & $\begin{array}{c}\text { Parts of the methodology are especially developed for } \\
\text { the pre-consumer biomass losses and therefore } \\
\text { potentially applicable in certification. }\end{array}$ \\
\hline
\end{tabular}

\subsection{Improvements in Livestock Production Efficiencies}

\subsubsection{General Description}

The rationale behind efficiency improvements in livestock production is to increase the productivity per unit area without taking more land into production. Therefore, this additionality practice is based on assumptions similar to those for increasing the production efficiency of existing agricultural crop production systems (compare Section 3.2.2). As Table 2 shows, only the iLUC risk assessment framework developed by Brinkman et al. [68] proposes a description and calculation methodology for this additionality practice. Information on the study of Brinkman et al. can be found in Table A1.

3.6.2. Approach to Determine the Amount of Low iLUC Risk Biomass from Improvements in Livestock Production Efficiencies

Method XIV. Regional Low iLUC Risk Potential from Improvements in Livestock Production Efficiencies

The approach, presented by Brinkman et al. [68], uses modelled data to determine the iLUC risk and to assess the low iLUC risk potential as a result of improved efficiencies in livestock production within a given region. The focus of this approach is on cattle production. A comparison of a baseline scenario with above baseline scenarios is carried out, similar to the approach presented under Method III (compare Section 3.2.2). For example, in a case study in Hungary, Brinkman et al. [85] assessed the 
low iLUC risk potential as a result of improvements in productivity per animal and animals per hectare, taking into account only grazing cows and sheep. A baseline was established assuming that there is no change in productivity. In contrast, three scenarios were assumed with an average linear increase in yields over a given period in the past (low), the best historical productivity in Hungary (medium) and the highest productivity in the EU27 (high). As a result, so-called surplus land in the low $\left(1630 \mathrm{~km}^{2}\right)$, medium $\left(3870 \mathrm{~km}^{2}\right)$, and high $\left(5170 \mathrm{~km}^{2}\right)$ areas could potentially be used for the production of low iLUC maize. Possible advantages and disadvantages of this method could be summarised as in Table 7 .

Table 7. Potential advantages and disadvantages of Method XIV.

\begin{tabular}{cc}
\hline Advantage & Disadvantage \\
\hline Comprehensive methodology. & Many input variables needs to be known. \\
In case studies approved methodology. & High complexity and effort in calculation methodology. \\
Projects a bandwidth for improved cattle density & Only applicable for certification by farms cultivating \\
and/or productivity. & agricultural cropland in addition. \\
& Methodology originally not developed for certification. \\
& High risk of environmental impacts and harm of animal \\
welfare due to livestock production intensification.
\end{tabular}

Own elaboration.

\section{Discussion}

\subsection{Importance to Develop a Low iLUC Risk Certification for Biobased Products}

The discussion about the iLUC risks of feedstock production based on agricultural crops focuses mainly on biofuels. In addition, in a growing BBE, iLUC risks could arise for other biobased products produced from agricultural crops. For example, an increase in demand for biobased plastics represents a huge potential for causing iLUC [91]. Several other studies indicate that the production and consumption of certain biobased products have a huge potential to increase the risk of iLUC [92-96]. It is, therefore, crucial to improve the methodology for determining the environmental impacts of iLUC within a growing BBE [97]. It can be assumed that iLUC increases the overall GHG emissions caused by the production of biobased products [98].

\subsection{Recommendations for a Robust and Practical Application of the Identified Additionality Practices in Certification Practice}

\subsubsection{Applicability and Potential Impacts of the Additionality Practices}

\section{Increased Agricultural Crop Yield}

We could identify five different additionality practices potentially applicable in certification of low iLUC risk biobased products. One of these practices is increased agricultural crop yield (compare Section 3.2). Our review revealed several approaches to how this practice might be implemented and verified in certification practice. We recommend intensifying the development of the Method $\mathrm{V}$, the moving trendline yield. The rationale for our recommendation is that this approach, on the one hand, could potentially combine the Methods I and II. On the other hand, the method considers especially variations in agricultural yields, e.g., due to varying weather conditions.

Peters et al. [70] presented the Method I and propose an approach where a basic yield for a given year is calculated taking into account production data from the last 10 years of the farm or group of farms. This is in line with suggestions made by Malins [77]. The period of 10 years seems to be adequate to determine a robust yield increase trendline, as proposed by several authors (compare $[70,77,78,80]$ ). However, in some cases this period is too short for a robust certification of low iLUC risk feedstock. This is primarily a concern considering the specific yield development within the life span of perennial crops (e.g., oil palm) [77]. In these cases, the period of data collection needs to be adjusted to the specific characteristics of the crop in scope. Malins [77] also recommends the certification of a group of 
farms and not just a single farm. This can result in lower effort for the auditing process, which could reduce the costs for the certification process, considerably.

For the Method II, Malins [77] suggests to take into account the annual trend yield increase based on regional or national data from the last 10 years of similar farms, as also proposed by Van de Staaij et al. [80] and the RSB [78]. According to Malins [77], especially the local trend of similar producers of the same crop and management methods within a given geographical area has to be considered for the establishment of the baseline yield. On the one hand, this could increase the effectiveness of the certification because the attained yield improvements of the producer proposed to be certified are linked to the overall yield improvements within a certain region. On the other hand, this approach might increase the effort for data gathering for the producer and the auditing process, because the yield data of the other farms needs to be collected.

Furthermore, Malins [77] proposes some adjustments in order to increase the accuracy of the Method I and II. This concerns, for example, the exclusion of extreme yield values in the calculation of the baseline yield. This proposal could require only a negligible higher effort, while it could considerably increase the accuracy of the baseline yield.

So far, however, the Method V seems to be underdeveloped, as it is only published in a comment of the International Council on Clean Transportation (icct) [83]. Therefore, further research is needed to develop a robust and verifiable methodology based on the moving trendline yield. However, in order to be able to certify the increase in agricultural yields effectively in practice, we recommend developing a methodology with as little complexity as possible.

Peters et al. [69] show in a case study region in Italy that the methodology developed by Peters et al. [70] to quantify increased yields in a multicropping system can be successfully applied to produce low iLUC risk biomass. The results imply to intensify the research on how yield improvements of multicropping systems could be verified for low iLUC risk certification.

\section{Biomass Cultivation on Unused Land}

We could identify two potential approaches for the assessment of biomass cultivation on unused land (compare Section 3.3.4). The Method VI deals with the harvested amount of feedstock of the plot of land in scope. Whereas, the Method VII takes into account a MYF. The MYF might be appropriate in specific cases. We recommend the development of a methodology based on both approaches. This could include a site-specific assessment tool taking into account remote sensing data and existing land use mapping tools (e.g. the SNV Siting Tool [99] or the Global Risk Assessment Service (GRAS) Tool, available online under www.gras-system.org [100]). The combination with existing tools could reduce the effort for data gathering and increase the comparison of different plots of unused land, as the tools use standardised data sets and land use categories.

Improved Production Chain Integration of Byproducts, Waste, and Residues

For the improved production chain integration of byproducts, waste, and residues, we identified several potentially applicable approaches. Methods VIII and IX seem to be very promising for analysis in possible follow-up studies, as both approaches were developed specifically for the certification of biobased products.

The use of residues has great potential for iLUC-free raw material production [101]. However, we recommend that follow-up studies analyse potential environmental impacts caused by the use of waste and residues as identified by Malins [102].

Although, the Method XI and XII are developed originally for the assessment at regional level, both approaches bear a huge potential to be included within the development of a low iLUC risk indicator. Both methods include a comprehensive and in case studies approved methodology (compare $[79,85,87,90])$. Especially, based on the Method XII, a methodology could be developed potentially applicable at the feedstock production and biomass conversion stage in the supply chain of biobased products. 
Based on the wide range of approaches identified and presented in Section 3.4.2, we recommend a comprehensive analysis of which identified method could be suitable for the certification process, taking into account high effectiveness and low effort for the certification practice. On the basis of the Method X, an additional additionality practice could be developed (compare $[77,80])$.

\section{Reduction in Biomass Losses}

The reduction of biomass losses, especially with the emphasis on food losses in the pre-consumer stages of the production chain (compare Method XIII), could be promising for the development of a low iLUC certification. This is why we propose further research on this topic. For example, food losses are of global importance [103], with enormous potential for biomass supply from loss reductions [104]. A substantial amount of land could be freed up by the reduction of food losses and wastes worldwide [105].

\section{Improvements in Livestock Production Efficiencies}

Improvements in livestock production efficiencies could only be applied by farms with other land use activities besides livestock production, preferably the production of agricultural crops [82]. In this way, Method XIV could be adapted to the project level in order to be eligible for certification of low iLUC risk biomass.

Methods Identified for the Product Certification and Regional Assessment

The methods identified to assess the outcome of the additionality practices have been developed for different purposes. On the one hand, we have identified methods that have been specifically developed for the certification of biomass with low iLUC risk. These methods are potentially directly applicable in the certification process of biobased products (compare Method I, II, IV, V, VI, VIII, IX, and X). On the other hand, we identified methods that have been developed for the assessment at the regional level (compare Method III, VII, XI, XII, XIII, and XIV). Although these approaches have been developed for another purpose than certification, the methods could serve as an instrument for regional risk assessment applied by certification schemes. Wicke et al. [67] propose to implement low iLUC risk indicators developed for regional assessment in certification schemes. However, the applicability of these indicators has only been tested in case studies at regional level in Europe $[85,87,106]$ and Indonesia [90]. Peters et al. [70] refer to the option of a regional certification approach that takes into account an entire geographical region. However, the authors do not specify this proposal in detail. El Takriti et al. [71] stress that there are several difficulties in implementing regional low iLUC risk approaches in certification, e.g., the demonstration of additionally produced biomass.

Van de Staaij et al. [80] emphasise that the application of low iLUC risk practices can only be realised within a chain of custody system with physical segregation or mass balance. Peters et al. [70] present a proposal on how low iLUC risk biobased products could be certified under a book and claim chain of custody approach.

\section{Potential Negative Impacts Caused by the Application of Additionality Practices}

In a technical report, published by the International Energy Agency (IEA) [107], the authors point out several potential effects that may be caused by the application of some of the additionality practices we have identified. A comprehensive overview of the potential negative effects of unsustainable applications of additionality practices in practice is provided by the STAR-ProBio project [82].

\subsubsection{Additionality Demonstration for Credible Low iLUC Risk Certification}

According to the RED 2, biomass with low iLUC risk must be produced in addition to usual feedstock production [22]. Therefore, several studies emphasise as a prerequisite for certification the importance of demonstrating that the production of feedstock for biobased products with low iLUC 
risk is additional compared to a business-as-usual (BAU) case $[70,71,75,77,78,80]$. The additionality tool of the Clean Development Mechanism (CDM) [108], originally intended to demonstrate additionality in GHG reduction projects, could serve as a model for the demonstration and assessment of additionality [77,84]. Van de Staaij et al. [80] point out that the certification mechanism must be effective, while the transaction costs of the process must be kept at an acceptable level. Therefore, Van de Staaij et al. [80] assess two important aspects, the free-rider potential and the transaction costs. The free-rider potential describes the potential for producers of feedstock for biobased products to be certified, even if they have not produced the feedstock in addition to a BAU case. Thus, the higher the free-rider potential, the less effective the certification system is. In order to analyse the transaction costs of certification, Van de Staaij et al. [80] introduce some proxies, e.g., easy verifiability by an auditor. Common to the approaches proposed by Peters et al. [70] and Van de Staaij et al. [80] is the preparation of an iLUC mitigation plan, which includes how the low iLUC risk biomass is intended to be produced. Malins [77] identifies several key characteristics of a credible certification, e.g., possible solutions to reduce the potential for free-riding and several proxy additionality rules. Furthermore, the author stresses the option to develop an additionality demonstration tool specifically tailored to the purpose of low iLUC risk certification.

\subsubsection{Development of Low iLUC Risk Indicators for Sustainability Certification Based on Identified Additionality Practices}

Based on the additionality practices identified in our review, we recommend the development of low iLUC risk indicators in follow-up studies. We especially suggest to intensify research activities related to the proposed examples of low iLUC risk indicators presented in Table 8. Furthermore, we present potential approaches and their main characteristics, which seem suitable for the development of the proposed indicators for sustainability certification.

Table 8. Examples of promising low iLUC risk indicators for sustainability certification based on identified additionality practices and potential approaches for implementation and verification.

\begin{tabular}{|c|c|c|}
\hline Low iLUC Risk Indicator & Method & Main Characteristic \\
\hline \multirow{4}{*}{ Improved yield $^{1}$} & Method I & Determines the trendline yield of the farm proposed to be certified. \\
\hline & Method II & $\begin{array}{c}\text { Determines the baseline yield based on yields of similar farms within a } \\
\text { certain geographical area. }\end{array}$ \\
\hline & Method IV & $\begin{array}{l}\text { Considers yield variations and credits low iLUC risk biomass based on the } \\
\text { successful implementation of a yield improvement plan and the } \\
\text { obtained yields. }\end{array}$ \\
\hline & Method V & $\begin{array}{l}\text { Considers yield variations and could potentially combine the Method I and } \\
\text { Method II. }\end{array}$ \\
\hline \multirow[t]{3}{*}{ Unused land ${ }^{2}$} & Method VI & $\begin{array}{l}\text { Determines low iLUC risk biomass from the cultivation of former unused } \\
\text { land based on the yield and size of the unused land plot. }\end{array}$ \\
\hline & Method VII & $\begin{array}{l}\text { Introduces a MYF to consider potential reduced yields on the former } \\
\text { unused land plot. }\end{array}$ \\
\hline & Method VIII & $\begin{array}{l}\text { Establishes a positive list based on identified specific feedstock-region } \\
\text { combinations and considers potential partial uses of the EoL product. }\end{array}$ \\
\hline \multirow[t]{3}{*}{ Chain integration ${ }^{3}$} & Method IX & $\begin{array}{l}\text { Establishes a simple input-output analysis based on identified low iLUC } \\
\text { risk feedstock (input) and manufactured biobased products (output). }\end{array}$ \\
\hline & Method X & $\begin{array}{l}\text { Establishes the direct interconnection between the feedstock production, } \\
\text { the production of biobased products and the use of byproducts within a } \\
\text { defined geographical area. }\end{array}$ \\
\hline & Method XII & $\begin{array}{l}\text { Considers the stage of feedstock production and biomass conversion in the } \\
\text { supply chain of biobased products. }\end{array}$ \\
\hline
\end{tabular}

\footnotetext{
${ }^{1}$ Improved agricultural crop yield, ${ }^{2}$ Biomass cultivation on unused land, ${ }^{3}$ Improved production chain integration
} of byproducts, waste, and residues.

An overview of how a credible indicator-based sustainability certification system could be developed is provided by van Dam et al. [109]. The authors point out recommendations and strategies for a successful implementation as well as limitations in establishing a certification system. Lewandowski and Faaij [110] present a description of how a certification system for sustainable bioenergy trade 
could be developed, including methods for formulating indicators to measure sustainability criteria, e.g., an indicator must be as specific and quantitative as possible. Meyer and Priess [111] assess the scope and quality of indicators used by certification schemes for bioenergy, forestry, and agriculture. The authors identified several requirements for the assessment of indicators, e.g., reliability and conceptual soundness. The results of the studies give an idea of which key criteria might be suitable for the development of low iLUC risk indicators.

Van Dam et al. [60] highlight the discussion whether and how iLUC could be included in sustainability certification. Amongst others, the authors point out the implementation of so-called promotion measures, which aim to reduce the negative impacts of iLUC [60]. The RSB might be treated as an international standard-setting organisation for low iLUC risk certification [112]. In a proposal for core principles of an iLUC mitigation credit system, such as verification, additionality, and auditing requirements, the authors discuss several iLUC mitigation measures and present recommendations for practical implementation [66]. Achterbosch et al. [113] analyse options for combining bioenergy production and food security with examples and recommendations for the project level. Hence, the additionality practices identified in our review are in line with relevant research and seem suitable for the development of low iLUC risk indicators in sustainability certification.

\subsection{Limitations of the Approach}

\subsubsection{Limitations of the Methodology Applied for this Review}

We can present a comprehensive picture of the current state of research on low iLUC risk practices potentially applicable for sustainability certification. However, the reference of the moving trendline yield (compare Method V) does not meet the requirements we have established for the literature under review (compare Section 2.1). This approach was published in a commentary by the icct [83] on the EC Delegated Regulation (EU) 2019/807 [22]. Nevertheless, we include the commentary in our analysis as it is recently published and deals amongst others with a methodology proposed for the certification of low iLUC risks. The approach presented by Spöttle et al. [79] is a tool to identify particularly low iLUC risk EoL streams at regional level and is, therefore, neither directly applicable to certification nor does it deal with different indicators like the other reviewed literature.

The low iLUC risk assessment frameworks presented in our review are mainly based on the LIIB Methodology developed by Van de Staaij et al. [80]. The certification approaches of the RSB [78] and Better Biomass [73] base on this methodology [114]. Furthermore, the proposals of Peters et al. [70] consider several aspects of the LIIB Methodology. In turn, the development of the LIIB Methodology was significantly influenced by the RCA methodology developed by Dehue et al. [75]. The Unused Land Guidance [81] can be grouped between the assessment approaches of the RCA and the LIIB Methodology. In addition, several studies reviewed were prepared by the consulting company ECOFYS Netherlands B.V. (e.g., [70,75,79-81]). Due to the close interdependence of the abovementioned approaches, a potential risk exists that the additionality practices and methods identified in our review are very close to each other, leaving less room for other potentially innovative approaches not presented by the studies prepared by ECOFYS. This could be an obstacle to open-ended research. However, in this review, we extend the view to other low iLUC risk assessment approaches to keep this risk as low as possible. Ultimately, we are in line with recently published studies also reviewing low iLUC risk approaches (compare [35,71,77]).

\subsubsection{Limitations of the Low iLUC Risk Certification Approach}

Although a credibly designed certification can potentially guarantee a certain level of sustainability, measures at the certification level alone are not sufficient to address the problem of iLUC [80]. Therefore, we discuss here how a certification approach could be supported by other policy instruments. The assessment of iLUC should be carried out for all land use sectors and not only for the biofuel sector [31]. Furthermore, certification needs to be complemented by additional measures, such as 
land use and sustainable land management policies for all agricultural crops at the global level [115]. This may include integrated land use planning activities aimed at preventing undesirable land use changes in all sectors [35]. The certification level could be supported with measures at regional, national, and international level [80]. In developing strategies to reduce the risk of iLUC, institutional structures and technology to increase overall soil productivity and protect soil ecosystem services must be strengthened [116].

The introduction of low iLUC risk biofuels may have the opposite effect as intended, namely an increase in the production of high iLUC risk feedstocks [117]. Several constraints could reduce the effectiveness of practices designed to mitigate LUC effects, e.g., uncertainties related to multipurpose feedstock (bioenergy and other uses) and the unavailability of annual land monitoring, especially for degraded and contaminated land [76]. Chalmers et al. [118] identify limitations and practical challenges that may be associated with the application of several additionality practices that we have investigated.

In a comparison of the LIIB Methodology with the ILUC Project ASsessment Tool (ILUC PAST), the authors identified several constraints of the LIIB Methodology, e.g., that the approach is time and labour intensive due to data collection and the involvement of local stakeholders [119]. However, this might also increase the accuracy of the LIIB approach.

\section{Conclusions and Research Demand}

We were able to show, among other things, that the modelling of GHG emissions caused by iLUC is carried out with a range of modelling approaches. These include economic models, combinations with Life Cycle Assessment, and approaches based on cause-effect relationships and simplified approaches with historical trend data. However, there are several other approaches to model iLUC effects, such as biophysical and system dynamic models. Based on the results of the different modelling approaches, we conclude on the one hand that iLUC is a key issue for the implementation of policies aimed at increasing the use of biofuels as a means to mitigate climate change. On the other hand, the modelling approaches do not provide clear information on the exact level of GHG emissions caused by iLUC for each biofuel path. Therefore, the EC has published several policies that address options on how to address iLUC of biofuel production. With the implementation of the RED 2 [21], which is supplemented by a delegated regulation [22], the concept of biofuels with high and low iLUC risk was established for the European biofuels market. According to this concept, a biofuel produced from a feedstock with a high iLUC risk, e.g., palm oil, can be certified as low iLUC risk biofuel if the feedstock producer produces the biomass in compliance with certain criteria. These criteria require the application of so-called additionality measures for the production of the biomass with low iLUC risk. Additionality measures include efficiency improvements in the agricultural production system of a biomass producer and the production of biomass feedstock on abandoned or degraded land.

On the basis of a literature review, we contribute to the identification and development of potentially suitable methods for the implementation and verification of additionality measures for certification practice. In the process, we have identified five potential practices for biomass production with low iLUC risk that are likely to be used by market actors. These are (i) increased agricultural crop yield, (ii) biomass cultivation on unused land, (iii) improved production chain integration of byproducts, waste, and residues, (iv) reductions in biomass losses, and (v) improvements in livestock production efficiencies. For each practice, we identified methods for the determination of feedstocks and products with low iLUC risk.

However, several key issues need to be considered for the implementation of the additionality practices in certification practice. It is, therefore, important that the biomass resulting from the application of additionality practices is produced in addition to a BAU case. Therefore, robust certification with low iLUC risk must significantly reduce the potential for free-riding. It is, therefore, necessary to avoid that biomass produced by producers whose feedstock production is not in addition to a BAU case is certified as low iLUC. In order to demonstrate that the biomass is produced in addition 
to a BAU case, several authors propose to use the CDM additionality tool [108] as a blueprint for developing an additionality tool especially for the low iLUC risk certification (e.g., [77]).

The results of our analysis will be used in follow-up activities, aiming to develop a framework for the assessment of different additionality practices in the context of low iLUC risk certification. The applicability and effectiveness of such an assessment approach will be tested with the help of case studies of biobased products.

Author Contributions: Conceptualization: B.S., S.M. and D.T.; Data curation: B.S.; Investigation: B.S. and S.M.; Methodology: B.S., S.M. and D.T.; Supervision: S.M. and D.T.; Validation: S.M. and D.T.; Formal analysis: B.S.; Writing—original draft preparation: B.S., S.M. and D.T.; Writing—review and editing: B.S., S.M. and D.T.; Visualization: B.S. All authors have read and agreed to the published version of the manuscript.

Funding: This research was funded by the European Union's Horizon 2020 research and innovation programme under grant agreement No. 727740.

Acknowledgments: The contents of the paper are a part of the findings of the project STAR-ProBio. STAR-ProBio has received funding from the European Union's Horizon 2020 research and innovation programme under grant agreement No. 727740. Re-use of information contained in this document for commercial and/or non-commercial purposes is authorised and free of charge, on the conditions of acknowledgement by the re-user of the source of the document, not distortion of the original meaning or message of the document and the non-liability of the STAR-ProBio consortium and/or partners for any consequence stemming from the re-use. The STAR-ProBio consortium does not accept responsibility for the consequences, errors or omissions herein enclosed. This document is subject to updates, revisions and extensions by the STAR-ProBio consortium. Questions and comments should be addressed to: http://www.star-probio.eu/contact-us/.

Conflicts of Interest: The authors declare no conflict of interest.

\section{Appendix A. Overview of Reviewed Studies Dealing with Low iLUC Risk Assessment Frameworks}

The Table A1 gives an overview of the studies we reviewed. It includes information about the following characteristics of the examined studies: (i) the reason, why the framework was developed; (ii) the application level (from project to regional to global/national level); (iii) the type of feedstock and/or biobased product the framework is dealing with; (iv) the geographical scope of the study, especially in regard to the location of available case studies; (v) whether the framework presents a detailed methodology to quantify potential low iLUC risk feedstocks and/or biobased products; (vi) the type of publication; and (vii) involved funding organisations. 
Table A1. Overview of reviewed studies dealing with low iLUC risk assessment frameworks. Several characteristics are listed for each study. These include, (i) the motivation to establish an assessment framework; (ii) the level of application, distinguished by project, regional, and global/national level; (iii) the type of feedstock or product in focus; (iv) the geographical scope of the study; (v) the availability of methodologies to quantify the amount of low iLUC risk feedstock/biobased product (Yes/No); (vi) the type of publication (e.g., report, certification scheme document, scientific journal article); (vii) the funding organisations; and (viii) the reference of the analysed document.

\begin{tabular}{|c|c|c|c|c|c|c|c|c|}
\hline Study Title & Motivation & $\begin{array}{c}\text { Application } \\
\text { Level }\end{array}$ & $\begin{array}{c}\text { Feedstock/Product } \\
\text { Type }\end{array}$ & $\begin{array}{c}\text { Geographical } \\
\text { Scope }\end{array}$ & $\begin{array}{l}\text { Quantification } \\
\text { Methodology }\end{array}$ & $\begin{array}{c}\text { Publication } \\
\text { Type }\end{array}$ & Funding & Reference \\
\hline $\begin{array}{l}\text { Sustainably produced } \\
\text { biomass for bioenergy and } \\
\text { biobased products-Part 1: } \\
\text { Sustainability requirements }\end{array}$ & $\begin{array}{l}\text { Providing possible solutions for market actors to } \\
\text { demonstrate that the biomass they use does not } \\
\text { lead to iLUC. }\end{array}$ & Project & $\begin{array}{l}\text { Bioenergy, biobased } \\
\text { products }\end{array}$ & Global & No & $\begin{array}{l}\text { Certification } \\
\text { scheme } \\
\text { document }\end{array}$ & NEN $^{1}$ & [73] \\
\hline $\begin{array}{l}\text { Regional level actions to } \\
\text { avoid ILUC-Phase } 1\end{array}$ & $\begin{array}{l}\text { Identification of measures that can be } \\
\text { implemented at regional level to mitigate iLUC } \\
\text { and identify possible indicators. }\end{array}$ & Regional & Biofuels & $\begin{array}{l}\text { Subnational regions, } \\
\text { countries, or supra- } \\
\text { national regions }\end{array}$ & No & $\begin{array}{l}\text { Technical } \\
\text { report }\end{array}$ & UK DfT $^{2}$ & [74] \\
\hline $\begin{array}{l}\text { Methodology for assessing } \\
\text { and quantifying ILUC } \\
\text { prevention options }\end{array}$ & $\begin{array}{l}\text { Providing knowledge on how iLUC risks can be } \\
\text { mitigated, quantified and regulated. }\end{array}$ & Regional & Biofuels & $\begin{array}{l}\text { Global (with case } \\
\text { studies in Poland, } \\
\text { Hungary, Romania, } \\
\text { Indonesia) }\end{array}$ & Yes & $\begin{array}{l}\text { Technical } \\
\text { report }\end{array}$ & $\begin{array}{l}\mathrm{RVO}^{3}, \mathrm{RIZA}^{4} \\
\text { Commissie } \\
\text { Corbey }^{5} \\
\mathrm{RCI} / \mathrm{PoR}^{6}\end{array}$ & [68] \\
\hline $\begin{array}{c}\text { Responsible Cultivation } \\
\text { Areas (RCA) }\end{array}$ & $\begin{array}{l}\text { Presentation of a workable set of voluntary } \\
\text { criteria and a methodology for identifying } \\
\text { specific areas and/or production models that can } \\
\text { be used for environmentally and socially } \\
\text { sustainable energy crop production with the least } \\
\text { possible unwanted direct and indirect impacts. }\end{array}$ & Project & Bioenergy, biofuels & Global & Yes /No & $\begin{array}{l}\text { Technical } \\
\text { report }\end{array}$ & $\begin{array}{l}\text { BP, Neste Oil, } \\
\text { SGSI }^{7}, \text { UK RFA }^{\text {RFA }} \\
{ }^{8} \text { DLPF }^{9}\end{array}$ & [75] \\
\hline $\begin{array}{l}\text { The Global Bioenergy } \\
\text { Partnership (GBEP) } \\
\text { Sustainability Indicators for } \\
\text { Bioenergy }\end{array}$ & $\begin{array}{l}\text { Evaluation of the role bioenergy production and } \\
\text { use plays in land use and land use change. }\end{array}$ & $\begin{array}{l}\text { Global/ } \\
\text { National }\end{array}$ & Bioenergy & $\begin{array}{c}\text { Individual } \\
\text { countries, globally }\end{array}$ & No & $\begin{array}{l}\text { Technical } \\
\text { report }\end{array}$ & $\begin{array}{l}\mathrm{BR}^{10}, \mathrm{DE}^{11}, \mathrm{IT}^{1} \\
{ }^{12}, \mathrm{NL}^{13}, \mathrm{UK}^{14} \\
\mathrm{USA}^{15}, \mathrm{FAO}^{16}\end{array}$ & [76] \\
\hline $\begin{array}{l}\text { Risk management- } \\
\text { Identifying high and low } \\
\text { ILUC-risk biofuels under } \\
\text { the recast Renewable } \\
\text { Energy Directive }\end{array}$ & $\begin{array}{l}\text { Amongst others, the presentation of suggestions } \\
\text { for an effective scheme for certifying low iLUC } \\
\text { risk projects as it is established by the } \\
\text { recast of the RED }{ }^{17} \text {. }\end{array}$ & Project & Biofuels & Global & Yes/No & $\begin{array}{l}\text { Technical } \\
\text { report }\end{array}$ & $\mathrm{T}^{\prime} \mathrm{E}^{18}$ & [77] \\
\hline $\begin{array}{l}\text { Methodologies for the } \\
\text { identification and } \\
\text { certification of Low ILUC } \\
\text { risk biofuels }\end{array}$ & $\begin{array}{l}\text { Proposal of methodologies to identify and } \\
\text { demonstrate additional low iLUC risk biofuel } \\
\text { feedstock production. }\end{array}$ & Project & Biofuels & Global & Yes & $\begin{array}{l}\text { Technical } \\
\text { report }\end{array}$ & $\mathrm{EC}^{19}$ & [70] \\
\hline $\begin{array}{l}\text { RSB }{ }^{20} \text { Low iLUC Risk } \\
\text { Biomass Criteria and } \\
\text { Compliance Indicators }\end{array}$ & $\begin{array}{l}\text { Presentation of the role of individual producers in } \\
\text { preventing indirect impacts and development of a } \\
\text { mechanism to promote biofuels with a lower risk } \\
\text { of causing negative indirect impacts. }\end{array}$ & Project & $\begin{array}{l}\text { Biofuels and } \\
\text { biomaterials }\end{array}$ & Global & Yes & $\begin{array}{l}\text { Certification } \\
\text { scheme } \\
\text { document }\end{array}$ & $\mathrm{RSB}^{20}$ & [78] \\
\hline $\begin{array}{l}\text { Low ILUC potential of } \\
\text { wastes and residues for } \\
\text { biofuels }\end{array}$ & $\begin{array}{l}\text { Assessment of the potential in the } \mathrm{EU}^{21} \text { of wastes } \\
\text { and residues with a low iLUC risk that can be } \\
\text { used for biofuel production. }\end{array}$ & Regional & $\begin{array}{l}\text { Biofuels from waste } \\
\text { and residues }\end{array}$ & $\begin{array}{l}\mathrm{EU}^{21} \text { Member } \\
\text { States and USA }{ }^{15}, \\
\text { China, Indonesia, } \\
\text { Argentina }\end{array}$ & Yes & $\begin{array}{l}\text { Technical } \\
\text { report }\end{array}$ & $\begin{array}{l}\mathrm{BMUB}^{22}, \mathrm{UBA} \\
23, \mathrm{FNR}^{24} \\
\mathrm{RIZA}^{4}, \mathrm{DEA}^{25}\end{array}$ & [79] \\
\hline
\end{tabular}


Table A1. Cont.

\begin{tabular}{|c|c|c|c|c|c|c|c|c|}
\hline Study Title & Motivation & $\begin{array}{c}\text { Application } \\
\text { Level }\end{array}$ & $\begin{array}{c}\text { Feedstock/Product } \\
\text { Type } \\
\end{array}$ & $\begin{array}{c}\text { Geographical } \\
\text { Scope }\end{array}$ & $\begin{array}{l}\text { Quantification } \\
\text { Methodology }\end{array}$ & $\begin{array}{c}\text { Publication } \\
\text { Type }\end{array}$ & Funding & Reference \\
\hline $\begin{array}{l}\text { Low Indirect Impact } \\
\text { Biofuel (LIIB) Methodology }\end{array}$ & $\begin{array}{l}\text { Presentation of a methodology for distinguishing } \\
\text { biofuels with a low risk of unwanted indirect } \\
\text { effects (LIIB), developed as an independent } \\
\text { module that can be added to existing certification } \\
\text { schemes and supports biofuel policy. }\end{array}$ & Project & Biofuels & $\begin{array}{l}\text { Global (with case } \\
\text { studies in Brazil, } \\
\text { Indonesia, } \\
\text { Mozambique, South } \\
\text { Africa) }\end{array}$ & Yes & $\begin{array}{l}\text { Technical } \\
\text { report }\end{array}$ & $\begin{array}{l}\text { BZ 26, NL } \\
\text { Agency }\end{array}$ & [80] \\
\hline Unused Land Guidance & $\begin{array}{l}\text { Guidance for producers of bioenergy feedstock to } \\
\text { assess whether a certain piece of land was unused } \\
\text { prior to project implementation with the aim of } \\
\text { avoiding indirect impacts. }\end{array}$ & Project & Bioenergy & Global & No & $\begin{array}{l}\text { Technical } \\
\text { report }\end{array}$ & NL Agency & [81] \\
\hline
\end{tabular}

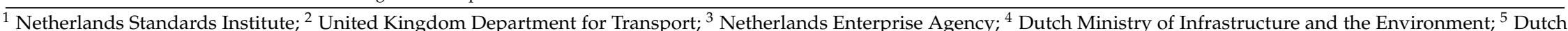
Sustainable Biomass Commission; ${ }^{6}$ Rotterdam Climate Initiative/Port of Rotterdam; ${ }^{7}$ Shell Global Solutions International; ${ }^{8}$ United Kingdom Renewable Fuels Agency; ${ }^{9}$ David and Lucile Packard Foundation; ${ }^{10}$ Brazil; ${ }^{11}$ Germany; ${ }^{12}$ Italy; ${ }^{13}$ The Netherlands; ${ }^{14}$ United Kingdom; ${ }^{15}$ United States of America; ${ }^{16}$ Food and Agriculture Organization of the United Nations; ${ }^{17}$ EU Renewable Energy Directive; ${ }^{18}$ Transport and Environment; ${ }^{19}$ European Commission; ${ }^{20}$ Roundtable on Sustainable Biomaterials; ${ }^{21}$ European Union; ${ }^{22}$ German Federal Ministry for the Environment; ${ }^{23}$ German Federal Environment Agency; ${ }^{24}$ German Fachagentur Nachwachsende Rohstoffe; ${ }^{25}$ Danish Energy Agency; ${ }^{26}$ Dutch Ministry of Foreign Affairs. 


\section{References}

1. Delbrück, S.; Griestop, L.; Hamm, U. Future Opportunities and Developments in the Bioeconomy: A Global Expert Survey; German Bioeconomy Council: Berlin, Germany, 2018.

2. Junginger, H.M.; Mai-Moulin, T.; Daioglou, V.; Fritsche, U.; Guisson, R.; Hennig, C.; Thrän, D.; Heinimö, J.; Hess, R.; Lamers, P.; et al. The future of biomass and bioenergy deployment and trade: A synthesis of 15 years IEA Bioenergy Task 40 on sustainable bioenergy trade. Biofuels. Bioprod. Bioref. 2019, 13, 247-266. [CrossRef]

3. Scarlat, N.; Dallemand, J.-F.; Monforti-Ferrario, F.; Nita, V. The role of biomass and bioenergy in a future bioeconomy: Policies and facts. Environ. Dev. 2015, 15, 3-34. [CrossRef]

4. Von Braun, J. Bioeconomy-The global trend and its implications for sustainability and food security. Glob. Food Secur. 2018, 19, 81-83. [CrossRef]

5. Daioglou, V.; Doelman, J.C.; Wicke, B.; Faaij, A.; van Vuuren, D.P. Integrated assessment of biomass supply and demand in climate change mitigation scenarios. Glob. Environ. Chang. 2019, 54, 88-101. [CrossRef]

6. Miyake, S.; Renouf, M.; Peterson, A.; McAlpine, C.; Smith, C. Land-use and environmental pressures resulting from current and future bioenergy crop expansion: A review. J. Rural Stud. 2012, 28, 650-658. [CrossRef]

7. Delzeit, R.; Zabel, F.; Meyer, C.; Václavík, T. Addressing future trade-offs between biodiversity and cropland expansion to improve food security. Reg. Environ. Chang. 2017, 17, 1429-1441. [CrossRef]

8. Goh, C.S.; Wicke, B.; Verstegen, J.; Faaij, A.; Junginger, M. Linking carbon stock change from land-use change to consumption of agricultural products: A review with Indonesian palm oil as a case study. J. Environ. Manag. 2016, 184, 340-352. [CrossRef]

9. Immerzeel, D.J.; Verweij, P.A.; van der Hilst, F.; Faaij, A.P.C. Biodiversity impacts of bioenergy crop production: A state-of-the-art review. GCB Bioenergy 2014, 6, 183-209. [CrossRef]

10. Allwood, J.M.; Bosetti, V.; Dubash, N.K.; Gómez-Echeverri, L.; Stechow, C.V. Glossary. In Climate Change 2014: Mitigation of Climate Change. Contribution of Working Group III to the Fifth Assessment Report of the Intergovernmental Panel on Climate Change; Edenhofer, O., Pichs-Madruga, R., Sokona, Y., Farahani, E., Kadner, S., Seyboth, K., Adler, A., Baum, I., Brunner, S., Eickemeier, P., et al., Eds.; Cambridge University Press: Cambridge, UK; New York, NY, USA, 2014; pp. 1249-1279.

11. Dumortier, J.; Hayes, D.J.; Carriquiry, M.; Dong, F.; Du, X.; Elobeid, A.; Fabiosa, J.F.; Tokgoz, S. Sensitivity of carbon emission estimates from indirect land-Use change. Appl. Econ. Perspect. Policy 2011, 33, 673. [CrossRef]

12. Meyfroidt, P.; Lambin, E.F.; Erb, K.-H.; Hertel, T.W. Globalization of land use: Distant drivers of land change and geographic displacement of land use. Curr. Opin. Environ. Sustain. 2013, 5, 438-444. [CrossRef]

13. Renewable Fuels Agency. The Gallagher Review of the Indirect Effects of Biofuels Production; Renewable Fuels Agency: St Leonards-on Sea, UK, 2008.

14. Villoria, N.B.; Hertel, T.W. Geography matters: International trade patterns and the indirect land use effects of biofuels. Am. J. Agric. Econ. 2011, 93, 919-935. [CrossRef]

15. Wicke, B.; Verweij, P.; van Meijl, H.; van Vuuren, D.P.; Faaij, A.P.C. Indirect land use change: Review of existing models and strategies for mitigation. Biofuels 2012, 3, 87-100. [CrossRef]

16. Fritsche, U.R.; Hennenberg, K.; Hünecke, K. The "iLUC Factor" as a Means to Hedge Risks of GHG Emissions from Indirect Land Use Change: Working Paper; Öko-Institut: Darmstadt, Germany, 2010.

17. Directive 2009/28/EC of the European Parliament and of the Council of 23 April 2009 on the Promotion of the Use of Energy from Renewable Sources and Amending and Subsequently Repealing Directives 2001/77/EC and 2003/30/EC: RED; European Commission: Brussels, Belgium, 2009.

18. Report from the Commission on Indirect Land-Use Change Related to Biofuels and Bioliquids COM (2010) 811 Final; European Commission: Brussels, Belgium, 2010.

19. Laborde, D. Assessing the Land Use Change Consequences of European Biofuel Policies: Final Report; IFPRI: Washington, DC, USA, 2011.

20. Valin, H.; Peters, D.; van den Berg, M.; Frank, S.; Havlik, P.; Forsell, N.; Hamelinck, C. The Land Use Change Impact of Biofuels Consumed in the EU: Quantification of Area and Greenhouse Gas Impacts; Ecofys, IIASA and E4tech: Utrecht, The Netherlands, 2015.

21. Directive (EU) 2018/2001 of the European Parliament and of the Council of 11 December 2018-On the Promotion of the Use of Energy from Renewable Sources (Recast): RED 2; European Commission: Brussels, Belgium, 2018. 
22. Commission Delegated Regulation (EU) 2019/807 of 13.3.2019 Supplementing Directive (EU) 2018/2001 of the European Parliament and of the Council as Regards the Determination of High Indirect Land-Use Change-Risk Feedstock for which a Significant Expansion of the Production Area into Land with High Carbon Stock is Observed and the Certification of Low Indirect Land-Use Change-Risk Biofuels, Bioliquids and Biomass Fuels; European Commission: Brussels, Belgium, 2019.

23. Edwards, R.; Mulligan, D.; Marelli, L. Indirect Land Use Change from Increased Biofuels Demand: Comparison of Models and Results for Marginal Biofuels Production from Different Feedstocks; EC JRC Institute for Energy: Ispra, Italy, 2010.

24. Commission Staff Working Document Impact Assessment Accompanying the Document Proposal for a Directive of the European Parliament and of the Council Amending Directive 98/70/EC Relating to the Quality of Petrol and Diesel Fuels and Amending Directive 2009/28/EC on the Promotion of the Use of Energy from Renewable Sources; European Commission: Brussels, Belgium, 2012.

25. Directive (EU) 2015/1513 of the European Parliament and of the Council—Of 9 September 2015-Amending Directive 98/70/EC Relating to the Quality of Petrol and Diesel Fuels and Amending Directive 2009/28/EC on the Promotion of the Use of Energy from Renewable Sources; European Commission: Brussels, Belgium, 2015.

26. Searchinger, T.; Heimlich, R.; Houghton, R.A.; Dong, F.; Elobeid, A.; Fabiosa, J.; Tokgoz, S.; Hayes, D.; $\mathrm{Yu}, \mathrm{T}$.-H. Use of U.S. croplands for biofuels increases greenhouse gases through emissions from land-use change. Science 2008, 319, 1238-1240. [CrossRef] [PubMed]

27. Fargione, J.; Hill, J.; Tilman, D.; Polasky, S.; Hawthorne, P. Land clearing and the biofuel carbon debt. Science 2008, 319, 1235-1238. [CrossRef]

28. Mathews, J.A.; Tan, H. Biofuels and indirect land use change effects: The debate continues. Biofuels Bioprod. Bioref. 2009, 3, 305-317. [CrossRef]

29. Croezen, H.J.; Bergsma, G.C.; Otten, M.B.J.; van Valkengoed, M.P.J. Biofuels: Indirect Land Use Change and Climate Impact; CE Delft: Delft, The Netherlands, 2010.

30. De Rosa, M.; Knudsen, M.T.; Hermansen, J.E. A comparison of land use change models: Challenges and future developments. J. Clean. Prod. 2016, 113, 183-193. [CrossRef]

31. Daioglou, V.; Woltjer, G.; Strengers, B.; Elbersen, B.; Ibañez, G.B.; Gonzalez, D.S.; Barno, J.G.; van Vuuren, D.P. Progress and barriers in understanding and preventing indirect land-use change. Biofuels Bioprod. Bioref. 2020, 98, 316. [CrossRef]

32. Panichelli, L.; Gnansounou, E. Impact of agricultural-based biofuel production on greenhouse gas emissions from land-use change: Key modelling choices. Renew. Sustain. Energy Rev. 2015, 42, 344-360. [CrossRef]

33. Henders, S.; Ostwald, M. Accounting methods for international land-related leakage and distant deforestation drivers. Ecol. Econ. 2014, 99, 21-28. [CrossRef]

34. Fehrenbach, H.; Giegrich, J.; Reinhardt, G.; Rettenmaier, N. Synopsis of Current Models and Methods Applicable to Indirect Land Use Change (ILUC): Report; IFEU: Heidelberg, Germany, 2009.

35. Woltjer, G.; Daioglou, V.; Elbersen, B.; Ibañez, G.B.; Smeets, E.; González, D.S.; Barnó, J.G. Study Report on Reporting Requirements on Biofuels and Bioliquids Stemming from the Directive (EU) 2015/1513; European Commission: Brussels, Belgium, 2017.

36. Al-Riffai, P.; Dimaranan, B.; Laborde, D. Global Trade and Environmental Impact Study of the EU Biofuels Mandate: Final Report; IFPRI: Washington, DC, USA, 2010.

37. Laborde, D.; Padella, M.; Edwards, R.; Marelli, L. Progress in Estimation of ILUC with MIRAGE Model: JRC Science and Policy Report; EC JRC Institute for Energy and Transport: Ispra, Italy, 2014.

38. Hertel, T.W.; Golub, A.A.; Jones, A.D.; O'Hare, M.; Plevin, R.J.; Kammen, D.M. Effects of US maize ethanol on global land use and greenhouse gas emissions: Estimating market-mediated responses. BioScience 2010, 60, 223-231. [CrossRef]

39. Tyner, W.E.; Taheripour, F.; Zhuang, Q.; Birur, D.; Baldos, U. Land Use Changes and Consequent $\mathrm{CO}_{2}$ Emissions due to US Corn Ethanol Production: A Comprehensive Analysis: Final Report; Department of Agricultural Economics Purdue University: West Lafayette, IN, USA, 2010.

40. Melillo, J.M.; Reilly, J.M.; Kicklighter, D.W.; Gurgel, A.C.; Cronin, T.W.; Paltsev, S.; Felzer, B.S.; Wang, X.; Sokolov, A.P.; Schlosser, C.A. Indirect emissions from biofuels: How important? Science 2009, 326, 1397-1399. [CrossRef] [PubMed] 
41. Plevin, R.J.; O’Hare, M.; Jones, A.D.; Torn, M.S.; Gibbs, H.K. Greenhouse gas emissions from biofuels' indirect land use change are uncertain but may be much greater than previously estimated. Environ. Sci. Technol. 2010, 44, 8015-8021. [CrossRef] [PubMed]

42. Acquaye, A.A.; Sherwen, T.; Genovese, A.; Kuylenstierna, J.; Lenny Koh, S.C.; McQueen-Mason, S. Biofuels and their potential to aid the UK towards achieving emissions reduction policy targets. Renew. Sustain. Energy Rev. 2012, 16, 5414-5422. [CrossRef]

43. Chen, R.; Qin, Z.; Han, J.; Wang, M.; Taheripour, F.; Tyner, W.; O'Connor, D.; Duffield, J. Life cycle energy and greenhouse gas emission effects of biodiesel in the United States with induced land use change impacts. Bioresour. Technol. 2018, 251, 249-258. [CrossRef] [PubMed]

44. Bauen, A.; Chudziak, C.; Vad, K.; Watson, P. A Causal Descriptive Approach to Modelling the GHG Emissions Associated with the Indirect Land Use Impacts of Biofuels: Final Report; E4tech: London, UK, 2010.

45. Baral, A.; Malins, C. Additional supporting evidence for significant iLUC emissions of oilseed rape biodiesel production in the EU based on causal descriptive modeling approach. GCB Bioenergy 2016, 8, 382-391. [CrossRef]

46. Tipper, R.; Hutchison, C.; Brander, M. A Practical Approach for Policies to Address GHG Emissions from Indirect Land Use Change Associated with Biofuels; Ecometrica: Edinburgh, UK, 2009.

47. Overmars, K.; Edwards, R.; Padella, M.; Prins, A.; Marelli, L. Estimates of Indirect Land Use Change from Biofuels Based on Historical Data; EC JRC Institute for Energy and Transport Sustainable Transport Unit: Ispra, Italy, 2015.

48. Plevin, R.J.; Beckman, J.; Golub, A.A.; Witcover, J.; O’Hare, M. Carbon accounting and economic model uncertainty of emissions from biofuels-induced land use change. Environ. Sci. Technol. 2015, 49, 2656-2664. [CrossRef]

49. Ahlgren, S.; Di Lucia, L. Indirect land use changes of biofuel production-A review of modelling efforts and policy developments in the European Union. Biotechnol. Biofuels 2014, 7. [CrossRef]

50. Broch, A.; Hoekman, S.K.; Unnasch, S. A review of variability in indirect land use change assessment and modeling in biofuel policy. Environ. Sci. Policy 2013, 29, 147-157. [CrossRef]

51. Nassar, A.M.; Harfuch, L.; Bachion, L.C.; Moreira, M.R. Biofuels and land-use changes: Searching for the top model. Interface Focus 2011, 1, 224-232. [CrossRef]

52. Frank, S.; Böttcher, H.; Havlík, P.; Valin, H.; Mosnier, A.; Obersteiner, M.; Schmid, E.; Elbersen, B. How effective are the sustainability criteria accompanying the European Union 2020 biofuel targets? GCB Bioenergy 2013, 5, 306-314. [CrossRef]

53. Directive 2009/30/EC of the European Parliament and of the Council of 23 April 2009 Amending Directive 98/70/EC as Regards the Specification of Petrol, Diesel and Gas-Oil and Introducing a Mechanism to Monitor and Reduce Greenhouse Gas Emissions and Amending Council Directive 1999/32/EC as Regards the Specification of Fuel Used by inland Waterway Vessels and Repealing Directive 93/12/EEC: FQD; European Commission: Brussels, Belgium, 2009.

54. Directive 98/70/EC of the European Parliament and of the Council of 13 October 1998 Relating to the Quality of Petrol and Diesel Fuels and Amending Council Directive 93/12/EEC; European Commission: Brussels, Belgium, 1998.

55. Report from the Commission to the European Parliament, the Council, the European Economic and Social Committee and the Committee of the Regions on the Status of Production of Relevant Food and Feed Crops Worldwide; European Commission: Brussels, Belgium, 2019.

56. Delzeit, R.; Klepper, G.; Söder, M. Indirect Land Use Change (iLUC) Revisited: An Evaluation of Current Policy Proposals; IFW: Kiel, Germany, 2017.

57. Gawel, E.; Ludwig, G. The iLUC dilemma: How to deal with indirect land use changes when governing energy crops? Land Use Policy 2011, 28, 846-856. [CrossRef]

58. Lange, M.; Delzeit, R. EU Biofuel Policies and The Regulation of Indirect Land Use Change; IFW: Kiel, Germany, 2012.

59. Creutzig, F.; Ravindranath, N.H.; Berndes, G.; Bolwig, S.; Bright, R.; Cherubini, F.; Chum, H.; Corbera, E.; Delucchi, M.; Faaij, A.; et al. Bioenergy and climate change mitigation: An assessment. GCB Bioenergy 2015, 7, 916-944. [CrossRef]

60. Van Dam, J.; Junginger, M.; Faaij, A.P.C. From the global efforts on certification of bioenergy towards an integrated approach based on sustainable land use planning. Renew. Sustain. Energy Rev. 2010, 14, 2445-2472. [CrossRef]

61. Finkbeiner, M. Indirect land use change-Help beyond the hype? Biomass Bioenergy 2014, 62, $218-221$. [CrossRef] 
62. Winickoff, D.E.; Mondou, M. The problem of epistemic jurisdiction in global governance: The case of sustainability standards for biofuels. Soc. Stud. Sci. 2017, 47, 7-32. [CrossRef]

63. Gawel, E.; Pannicke, N.; Hagemann, N. A path transition towards a bioeconomy-The crucial role of sustainability. Sustainability 2019, 11, 3005. [CrossRef]

64. Majer, S.; Wurster, S.; Moosmann, D.; Ladu, L.; Sumfleth, B.; Thrän, D. Gaps and research demand for sustainability certification and standardisation in a sustainable bio-based economy in the EU. Sustainability 2018, 10, 2455. [CrossRef]

65. STAR-ProBio. STAR-ProBio Deliverable D7.1 Examination of Existing ILUC Approaches and their Application to Bio-Based Materials; Unitelma Sapienza University: Rome, Italy, 2018.

66. Ernst \& Young. Biofuels and Indirect Land Use Change: The Case for Mitigation; Ernst \& Young: London, UK, 2011.

67. Wicke, B.; Brinkman, M.L.J.; Gerssen-Gondelach, S.; van der Laan, C.; Faaij, A.P.C. ILUC Prevention Strategies for Sustainable Biofuels: Synthesis Report from the ILUC Prevention Project; Copernicus Institute of Sustainable Development, Utrecht University: Utrecht, The Netherlands, 2015.

68. Brinkman, M.; Wicke, B.; Gerssen-Gondelach, S.; van der Laan, C.; Faaij, A. Methodology for Assessing and Quantifying ILUC Prevention Options: ILUC Prevention Project-Methodology Report; Copernicus Institute of Sustainable Development, Utrecht University: Utrecht, The Netherlands, 2015.

69. Peters, D.; Zabeti, M.; Kühner, A.-K.; Spöttle, M.; van der Werf, W.; Stomph, T.J. Assessing the Case for Sequential Cropping to Produce Low ILUC Risk Biomethane: Final Report; Ecofys: Utrecht, The Netherlands, 2016.

70. Peters, D.; Spöttle, M.; Hähl, T.; Kühner, A.-K.; Cuijpers, M.; Stomph, T.J.; van der Werf, W.; Grass, M. Methodologies for the Identification and Certification of Low ILUC Risk Biofuels: Final Report; Ecofys: Utrecht, The Netherlands, 2016.

71. El Takriti, S.; Malins, C.; Searle, S. Understanding Options for ILUC Mitigation; ICCT: Washington, DC, USA, 2016.

72. Fritsche, U.R.; Sims, R.E.H.; Monti, A. Direct and indirect land-use competition issues for energy crops and their sustainable production-An overview. Biofuels Bioprod. Bioref. 2010, 4, 692-704. [CrossRef]

73. Better Biomass. NCS-8080-1: Sustainably Produced Biomass for Bioenergy and Bio-Based Products-Part 1: Sustainability Requirements; NEN: Delft, The Netherlands, 2015.

74. Brander, M.; Low, R.; Tipper, R. Regional Level Actions to Avoid ILUC_Phase 1: Report to the Department for Transport; Ecometrica: Edinburgh, UK, 2010.

75. Dehue, B.; Meyer, S.; van de Staaij, J. Responsible Cultivation Areas: Identification and Certification of Feedstock Production with a Low Risk of Indirect Effects; Ecofys: Utrecht, The Netherlands, 2010.

76. Global Bioenergy Partnership. The Global Bioenergy Partnership Sustainability Indicators for Bioenergy: First Edition; Office of Knowledge Exchange, Research and Extension, FAO: Rome, Italy, 2011.

77. Malins, C. Risk Management: Identifying High and Low ILUC-Risk Biofuels under the Recast Renewable Energy Directive; Cerulogy: London, UK, 2019.

78. Roundtable on Sustainable Biomaterials. RSB Low iLUC Risk Biomass Criteria and Compliance Indicators: Version 0.3; RSB: Geneva, Switzerland, 2015.

79. Spöttle, M.; Alberici, S.; Toop, G.; Peters, D.; Gamba, L.; Ping, S.; van Steen, H.; Bellefleur, D. Low ILUC Potential of Wastes and Residues for Biofuels: Straw, Forestry Residues, UCO, Corn Cobs; Ecofys: Utrecht, The Netherlands, 2013.

80. Van de Staaij, J.; Peters, D.; Dehue, B.; Meyer, S.; Schueler, V.; Toop, G.; Junquery, V.; Máthé, L. Low Indirect Impact Biofuel (LIIB) Methodology: Version 0; Ecofys, EPFL and WWF: Utrecht, The Netherlands, 2012.

81. Van de Staaij, J.; Peters, D.; Schueler, V.; Meyer, S.; Toop, G. Unused Land Guidance: Approach to Assess Land Use Prior to Bioenergy Feedstock Production; Ecofys: Utrecht, The Netherlands, 2012.

82. STAR-ProBio. STAR-ProBio Deliverable D7.2: Land Use Change Assessment for Case Studies of Bio-Based Products; Unitelma Sapienza University: Rome, Italy, 2019.

83. Searle, S. ICCT Comments on the Commission Delegated Regulation on High and Low Indirect Land Use Change Risk Feedstocks and Biofuels; ICCT: Washington, DC, USA, 2019.

84. Searle, S.; Giuntoli, J. Analysis of High and low Indirect Land-Use Change Definitions in European Union Renewable Fuel Policy; ICCT: Washington, DC, USA, 2018.

85. Brinkman, M.L.J.; Wicke, B.; Faaij, A.P.C. Low-ILUC-risk ethanol from Hungarian maize. Biomass Bioenergy 2017, 99, 57-68. [CrossRef] 
86. Wiegmann, K.; Hennenberg, K.; Fritsche, U.R. Degraded Land and Sustainable Bioenergy Feedstock Production: Issue Paper; Öko-Institut: Darmstadt, Germany, 2008.

87. Brinkman, M.L.J.; van der Hilst, F.; Faaij, A.P.C.; Wicke, B. Low-ILUC-risk rapeseed biodiesel: Potential and indirect GHG emission effects in Eastern Romania. Biofuels 2018, 52, 1-16. [CrossRef]

88. Scarlat, N.; Martinov, M.; Dallemand, J.-F. Assessment of the availability of agricultural crop residues in the European Union: Potential and limitations for bioenergy use. Waste Manag. 2010, 30, 1889-1897. [CrossRef] [PubMed]

89. Directive 2008/98/EC on Waste and Repealing Certain Directives; European Commission: Brussels, Belgium, 2008.

90. Van der Laan, C.; Wicke, B.; Verweij, P.A.; Faaij, A.P.C. Mitigation of unwanted direct and indirect land-use change-An integrated approach illustrated for palm oil, pulpwood, rubber and rice production in North and East Kalimantan, Indonesia. GCB Bioenergy 2017, 9, 429-444. [CrossRef]

91. Escobar, N.; Haddad, S.; Börner, J.; Britz, W. Land use mediated GHG emissions and spillovers from increased consumption of bioplastics. Environ. Res. Lett. 2018, 13,1-13. [CrossRef]

92. Alvarenga, R.A.F.; Dewulf, J.; de Meester, S.; Wathelet, A.; Villers, J.; Thommeret, R.; Hruska, Z. Life cycle assessment of bioethanol-based PVC: Part 2: Consequential approach. Biofuels Bioprod. Bioref. 2013, 396-405. [CrossRef]

93. Belboom, S.; Léonard, A. Importance of LUC and ILUC on the carbon footprint of bioproduct: Case of bio-HDPE. Matériaux Tech. 2014, 102. [CrossRef]

94. Eerhart, A.J.J.E.; Faaij, A.P.C.; Patel, M.K. Replacing fossil based PET with biobased PEF; process analysis, energy and GHG balance. Energy Environ. Sci. 2012, 5, 6407. [CrossRef]

95. Parajuli, R.; Knudsen, M.T.; Birkved, M.; Djomo, S.N.; Corona, A.; Dalgaard, T. Environmental impacts of producing bioethanol and biobased lactic acid from standalone and integrated biorefineries using a consequential and an attributional life cycle assessment approach. Sci. Total Environ. 2017, 598, 497-512. [CrossRef]

96. Piemonte, V.; Gironi, F. Land-use change emissions: How green are the bioplastics? Environ. Prog. Sustain. Energy 2011, 30, 685-691. [CrossRef]

97. Martin, M.; Røyne, F.; Ekvall, T.; Moberg, Å. Life cycle sustainability evaluations of bio-based value chains: Reviewing the indicators from a swedish perspective. Sustainability 2018, 10, 547. [CrossRef]

98. Weiss, M.; Haufe, J.; Carus, M.; Brandão, M.; Bringezu, S.; Hermann, B.; Patel, M.K. A review of the environmental impacts of biobased materials. J. Ind. Ecol. 2012, 16, S169-S181. [CrossRef]

99. Mallet, P.; Maireles, M.; Kennedy, E.; Devisscher, M. How Sustainability Standards Can Contribute to Landscape Approaches and Zero Deforestation Commitments; ISEAL Alliance: London, UK, 2016.

100. Global Risk Assessment Services GmbH. GRAS Tool. Available online: https://www.gras-system.org/ (accessed on 24 July 2020).

101. Prade, T.; Björnsson, L.; Lantz, M.; Ahlgren, S. Can domestic production of iLUC-free feedstock from arable land supply Sweden's future demand for biofuels? J. Land Use Sci. 2017, 12, 407-441. [CrossRef]

102. Malins, C. Waste not Want not: Understanding the Greenhouse Gas Implications of Diverting Waste and Residual Materials to Biofuel Production; Cerulogy: London, UK, 2017.

103. Food and Agriculture Organization of the United Nations. Global Food Losses and Food Waste: Extent, Causes and Prevention; FAO: Rome, Italy, 2011.

104. Xue, L.; Liu, G.; Parfitt, J.; Liu, X.; van Herpen, E.; Stenmarck, Å.; O’Connor, C.; Östergren, K.; Cheng, S. Missing food, missing data? A critical review of global food losses and food waste data. Environ. Sci. Technol. 2017, 51, 6618-6633. [CrossRef] [PubMed]

105. Skeer, J.; Nakada, S. Potential for biomass and biofuel through sustainable intensification of agriculture and reduction of food losses and waste. Nat. Resour. 2016, 7, 23-27. [CrossRef]

106. Gerssen-Gondelach, S.J.; Wicke, B.; Borzęcka-Walker, M.; Pudełko, R.; Faaij, A.P.C. Bioethanol potential from miscanthus with low ILUC risk in the province of Lublin, Poland. GCB Bioenergy 2016, 8, 909-924. [CrossRef]

107. Berndes, G.; Bird, N.; Cowie, A. Bioenergy Land Use Change and Climate Change Mitigation: Background Technical Report; IEA Bioenergy: Rotorua, New Zealand, 2011.

108. Clean Development Mechanism Executive Board. Methodological Tool: Tool for the Demonstration and Assessment of Additionality, Version 7.0.0; UN Framework Convention on Climate Change: Bonn, Germany, 2012.

109. Van Dam, J.; Junginger, M.; Faaij, A.; Jürgens, I.; Best, G.; Fritsche, U. Overview of recent developments in sustainable biomass certification. Biomass Bioenergy 2008, 32, 749-780. [CrossRef] 
110. Lewandowski, I.; Faaij, A.P.C. Steps towards the development of a certification system for sustainable bio-energy trade. Biomass Bioenergy 2006, 30, 83-104. [CrossRef]

111. Meyer, M.A.; Priess, J.A. Indicators of bioenergy-related certification schemes-An analysis of the quality and comprehensiveness for assessing local/regional environmental impacts. Biomass Bioenergy 2014, 65, 151-169. [CrossRef]

112. United Nations Conference on Trade and Development. Second Generation Biofuel Market: State of Play, Trade and Developing Countries Perspective; UNCTAD: Geneva, Switzerland, 2016.

113. Achterbosch, T.; Meijerink, G.; Slingerland, M.; Smeets, E. Combining Bioenergy Production and Food Security; LEI Wageningen University \& Research: Wageningen, The Netherlands, 2013.

114. Ramirez-Contreras, N.E.; Faaij, A.P.C. A review of key international biomass and bioenergy sustainability frameworks and certification systems and their application and implications in Colombia. Renew. Sustain. Energy Rev. 2018, 96, 460-478. [CrossRef]

115. Scarlat, N.; Dallemand, J.-F. Recent developments of biofuels/bioenergy sustainability certification: A global overview. Energy Policy 2011, 39, 1630-1646. [CrossRef]

116. Witcover, J.; Yeh, S.; Sperling, D. Policy options to address global land use change from biofuels. Energy Policy 2013, 56, 63-74. [CrossRef]

117. Malins, C. Low ILUC-Risk; High Loophole Risk? 2015. Available online: https://theicct.org/blogs/staff/low-ilucrisk-high-loophole-risk (accessed on 21 July 2020).

118. Chalmers, J.; Kunen, E.; Ford, S.; Harris, N.; Kadyzewski, J. Biofuels and Land Use Change: White Paper: Challenges and Opportunities for Improved Assessment and Monitoring; Winrock International: Arlington, VA, USA, 2011.

119. Di Lucia, L.; Sevigné-Itoiz, E.; Peterson, S.; Bauen, A.; Slade, R. Project level assessment of indirect land use changes arising from biofuel production. GCB Bioenergy 2019, 11, 1361-1375. [CrossRef]

(C) 2020 by the authors. Licensee MDPI, Basel, Switzerland. This article is an open access article distributed under the terms and conditions of the Creative Commons Attribution (CC BY) license (http://creativecommons.org/licenses/by/4.0/). 